\title{
Lessons Learned from Alternative Transportation Fuels: Modeling Transition Dynamics
}

Technical Report NREL/TP-540-39446

February 2006

C. Welch 
Lessons Learned from Alternative Transportation Fuels: Modeling Transition Dynamics

C. Welch

Prepared under Task Nos. HS04.2000 and HS06.1002
Technical Report NREL/TP-540-39446

February 2006

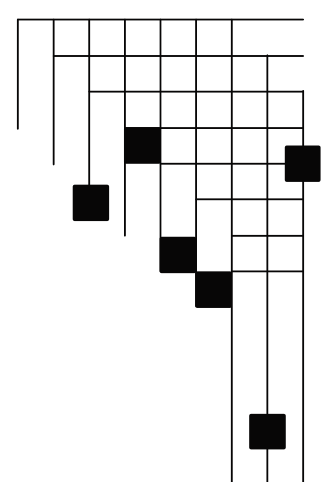




\section{NOTICE}

This report was prepared as an account of work sponsored by an agency of the United States government. Neither the United States government nor any agency thereof, nor any of their employees, makes any warranty, express or implied, or assumes any legal liability or responsibility for the accuracy, completeness, or usefulness of any information, apparatus, product, or process disclosed, or represents that its use would not infringe privately owned rights. Reference herein to any specific commercial product, process, or service by trade name, trademark, manufacturer, or otherwise does not necessarily constitute or imply its endorsement, recommendation, or favoring by the United States government or any agency thereof. The views and opinions of authors expressed herein do not necessarily state or reflect those of the United States government or any agency thereof.

Available electronically at http://www.osti.gov/bridge

Available for a processing fee to U.S. Department of Energy and its contractors, in paper, from:

U.S. Department of Energy

Office of Scientific and Technical Information

P.O. Box 62

Oak Ridge, TN 37831-0062

phone: 865.576 .8401

fax: 865.576 .5728

email: mailto:reports@adonis.osti.gov

Available for sale to the public, in paper, from:

U.S. Department of Commerce

National Technical Information Service

5285 Port Royal Road

Springfield, VA 22161

phone: 800.553 .6847

fax: 703.605.6900

email: orders@ntis.fedworld.gov

online ordering: http://www.ntis.gov/ordering.htm 


\section{Table of Contents}

TABLE OF CONTENTS ......................................................................................................................................

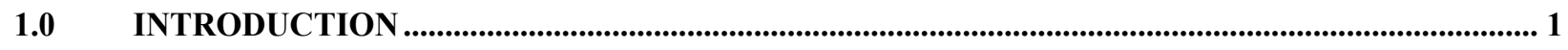

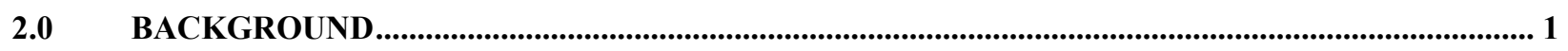

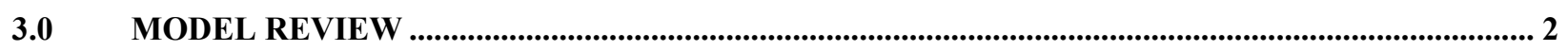

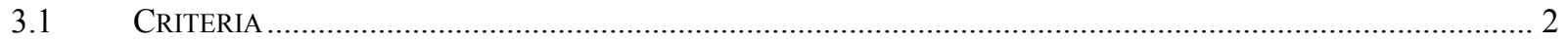

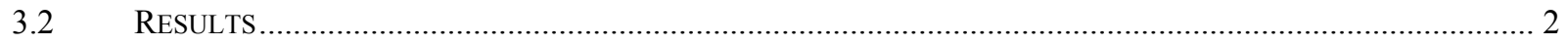

4.0 NREL/MIT COLLABORATION ........................................................................................................... 3

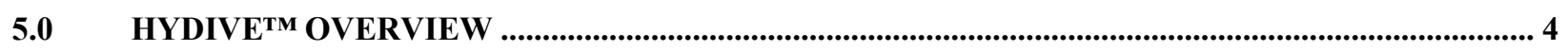

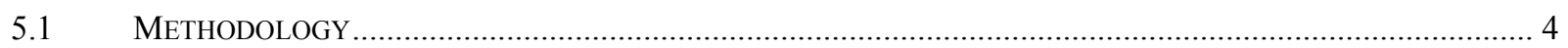

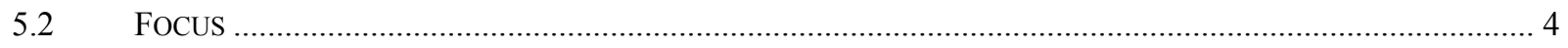

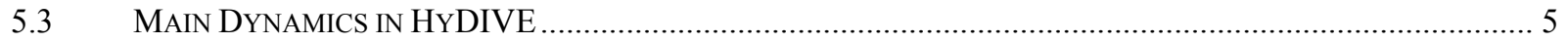

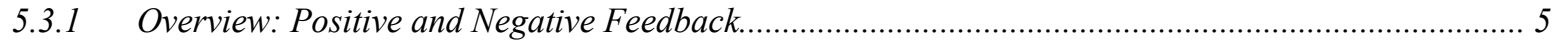

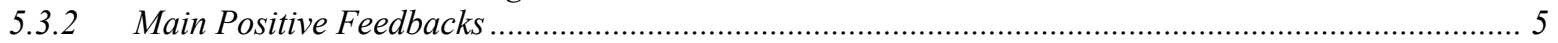

5.3.3 Main Negative Feedbacks........................................................................................................ 8

5.3.4 Spatial Interdependence between Vehicle Demand and Station Coverage ........................................... 9

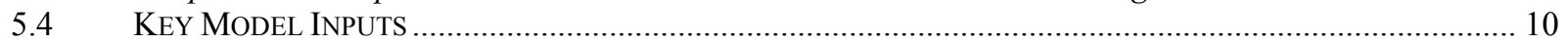

6.0 PRELIMINARY SIMULATIONS AND MODEL OUTPUT .............................................................. 12

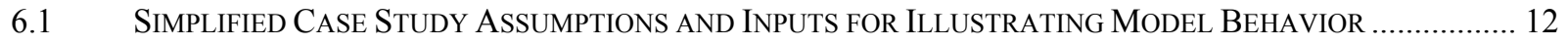

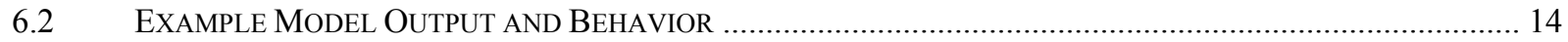

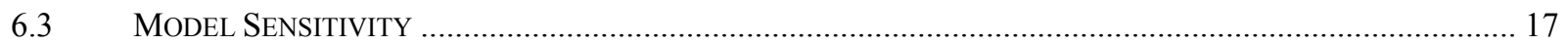

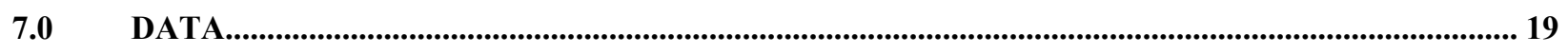

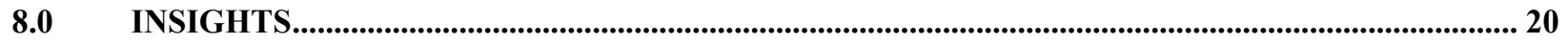

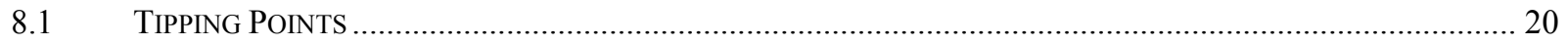

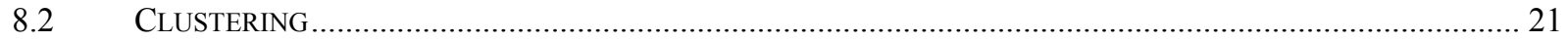

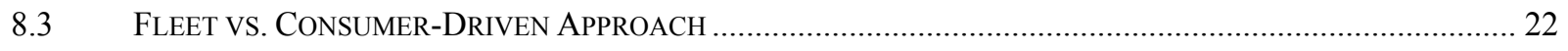

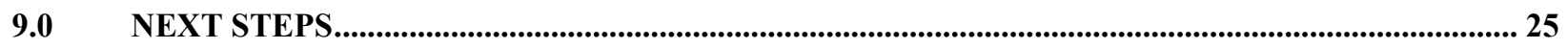

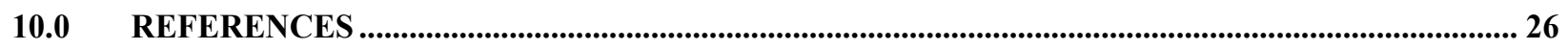

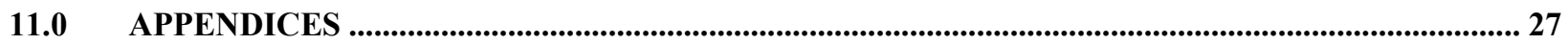




\subsection{Introduction}

In recent years, much attention has been given to the use of hydrogen as an alternative transportation fuel. Industry and government have already invested hundreds of millions of dollars to develop the technologies necessary to transition to a "hydrogen economy." However, hydrogen was certainly not the first fuel considered as an alternative to gasoline for transportation applications. Options ranging from all-electric vehicles to those running on natural gas, propane, ethanol, and biodiesel have also received both industry and government attention as potential substitutes for the conventional gasoline-powered internal combustion engine (ICE). Unfortunately, previous government efforts to encourage widespread adoption of alternative fuel vehicles have been largely unsuccessful. Examples include the failed attempt to mandate a significant percentage of zero emission vehicles in California as well as the recognition that petroleum displacement has fallen far short of the Energy Policy Act (1992) [1] goal of 10\% by the year 2000 and will also miss the goal of 30\% displacement by the year 2010 .

A strong tendency in such failed attempts is to attribute failure to individual causes, such as higher vehicle purchase or operating costs, poor vehicle performance, low refueling (or recharging) station coverage, or inadequate government incentives. However, such simplistic attributions fail to consider the entire system and do not appreciate the complexity of overcoming a highly entrenched technology such as the gasoline ICE. Additionally, solutions that encourage alternative-fueled-vehicle adoption often only consider the end states, such as target vehicle or fuel production cost at high volume or large-scale "optimized" solutions to fuel distribution, with little consideration given to the transitional dynamics that would lead to realizing these end states. Recognizing the importance of transitional issues, the National Academy of Engineering [2] suggested that "the DOE might have its greatest impact by leading the private economy toward transition strategies rather than to ultimate visions of an energy infrastructure markedly different from the one now in place" and that "the policy analysis capability of the Department of Energy with respect to the hydrogen economy should be strengthened, and the role of government in supporting and facilitating industry investments to help bring about a transition to a hydrogen economy needs to be better understood." To better understand the challenges of attempting to displace petroleum-derived fuels, a systems approach is required.

\subsection{Background}

To maximize the likelihood of a successful transition to a hydrogen based transportation system, it is vital that we develop a better understanding of the complex forces that have contributed to previously unsuccessful transition attempts, as these forces will inevitably still be at play in any attempt to displace gasoline ICE's with hydrogen-powered vehicles. To facilitate improved understanding of the lessons learned from previous attempts to introduce alternative-fueled vehicles, the Systems Integration office at the National Renewable Energy Laboratory (NREL) funded a small initial research effort. The first part of this effort focused on experiential lessons learned as identified through literature research and stakeholder feedback and is documented in 
reference [3]. The second part of this effort, which is the subject of this report, focused on understanding how analytical system modeling coupled with actual data from previous alternative-fuel experiences could improve our understanding of the dynamic forces governing the transition to an alternative-fuel-vehicle (AFV) system.

\subsection{Model Review}

\subsection{Criteria}

In the initial phase of this project, researchers surveyed existing literature to find analytical models that could shed light on transition dynamics and that could also benefit from existing data from previous alternative-fueled-vehicle experiences - in particular, data contained within the Alternative Fuels Data Center (AFDC) [4] at NREL. While a variety of models were reviewed for completeness, the main objective was to identify models existing or under development that:

1. are dynamic (i.e., change with time),

2. focus on the hydrogen transition, and

3. contain endogenous vehicle demand and refueling infrastructure growth.

The rationale for these criteria is as follows. First, it is generally accepted that a transition to a hydrogen-based transportation system would take several decades, during which many important modeling inputs would change. Critical elements of the hydrogen transition, such as the performance and cost of hydrogen vehicles, the growth of a hydrogen infrastructure, and the turnover of existing vehicle inventory are all both highly dependent on time and interdependent. Dynamic, as compared with static, models are better suited to represent these temporal and interdependent elements of the transition and thus were the focus of this study. Second, while "end-game" analyses are required to understand where we would like to go, models that focus on the transitional issues are required to understand how to get there. Finally, an oft repeated key barrier to a hydrogen-based transportation system is the "chicken-and-egg" dilemma associated with a lack of refueling infrastructure to support vehicles running on a fuel other than gasoline. The significance of this barrier was further highlighted by the results of the first part of this study (see reference [3]). Thus, the third criterion required that a transition model represent the interdependent growth of both hydrogen vehicle demand and hydrogen refueling station coverage.

\subsection{Results}

Although numerous models exist that address important elements of a hydrogen-based transportation system, only the three models identified below satisfied simultaneously the above criteria. 


\section{HyTRANS (Oak Ridge National Laboratory)}

HyTRANS (short for Hydrogen Transition) is a model being developed by Oak Ridge National Laboratory (ORNL) that addresses various elements of the hydrogen transition [5]. It evolved from the TAFV (Transitional Alternative Fuels and Vehicles) model [6], but has been modified to focus on hydrogen rather than on an array of alternative fuels. The model is transitional in nature, has dynamic elements (such as learning curves), and contains a highlevel coupling between hydrogen vehicle demand and refueling station coverage.

\section{Complex Adaptive System (CAS) Model (RCF Consulting and Argonne National} Laboratory)

A complex adaptive system model analyzing the evolution of a hydrogen infrastructure is in the initial stages of development by RCF Consulting in collaboration with Argonne National Laboratory (ANL) and various industry and academic partners [7]. This model will use agent-based modeling techniques to improve our understanding of how the transition to a hydrogen infrastructure might occur. This model will be dynamic, address transitional issues, and intends to link hydrogen infrastructure with vehicle demand [8], although the nature of this link had not yet been determined at the time of the model review.

3. Dynamic, Behavioral, Spatial System Dynamics Model (Massachusetts Institute of Technology (MIT))

A dynamic, behavioral, spatial model using System Dynamics as a framework was under development by MIT [9] at the time of this model review (June, 2005). The model simulated in one dimension the spatial, dynamic interaction between hydrogen refueling station coverage and hydrogen vehicle demand (a dynamic we consider to be particularly important for the hydrogen transition - see Section 5.3.4), and considered technical, economic, and behavioral parameters for both supply (i.e., refueling stations) and demand (i.e., vehicle/fuel purchases). The model was under development as part of a larger project to explore all the critical feedbacks associated with transitioning to a hydrogen-based transportation system.

\subsection{NREL/MIT Collaboration}

Although both the ORNL and the ANL models may potentially shed light on transitional issues as well as benefit from existing alternative fuels data, this project initiated collaboration between NREL and MIT for a number of reasons. First, the methodology of System Dynamics being used by MIT is particularly useful for studying transitional issues (see Section 5.1 for elaboration on the methodology). Second, the MIT model endeavored to link in rigorous manner hydrogen refueling station coverage with hydrogen vehicle demand. The lack of refueling station coverage is a significant "chicken-and-egg" barrier that is not yet well understood but that can have a major impact on the ultimate widespread adoption of hydrogen vehicles. Thus, a rigorous analysis of this barrier is expected to shed light on previously attempted AFV introductions as 
well as inform future hydrogen transition strategies. Third, a partnership between NREL and MIT was considered to be valuable in that MIT is the world leader in the field of System Dynamics and NREL has broad knowledge of alternative fueled vehicle attempts through its extensive involvement over its nearly 30-year history in DOE's alternative fuel programs including Clean Cities, EPAct Fleet Regulatory Programs, and the Advanced Vehicle Testing Activity. Data and information from these programs and the alternative fuels industry are maintained at NREL for DOE in the Alternative Fuels Data Center. The AFDC contains a wide range of historical data on alternative fuels including fueling station locations, available vehicle models, federal and state incentives and laws. Finally, the limited resources and scope of this project required a focused effort, thereby limiting the cross-organization collaboration that could be pursued.

\subsection{HyDIVE ${ }^{\mathrm{TM}}$ Overview}

This section briefly summarizes the methodology and major elements of the model [10] developed by MIT under subcontract [11] and in cooperation with NREL. More detailed documentation of this model is provided by reference [12]. When used by NREL for transition strategy analysis, this model will be referenced as the HyDIVE (Hydrogen Dynamic Infrastructure and Vehicle Evolution) model.

\subsection{Methodology}

The field of System Dynamics was invented at MIT in the 1950s. It is grounded "in the theory of nonlinear dynamics and feedback control" [13], which is used to simulate the behavior of complex physical systems. The concepts of feedback, control, delays, and state variables (referred to as "stocks" in the field of System Dynamics) were discovered to have applications in business, economic, and social systems as well. Since its invention, System Dynamics has been used in industry, academia, and government to shed light on problems that traditional analysis methods are unable to explain.

The transition to a hydrogen-based transportation system is complex and will require interaction (and in some cases cooperation) among multiple stakeholders. It will also take several decades to realize. The "fundamentally interdisciplinary" nature of System Dynamics [13], combined with its temporal approach and incorporation of feedback make it especially conducive to analyzing a long-term, complex, system problem such as the transition to a hydrogen-based transportation system.

\subsection{Focus}

Although myriad time-dependent phenomena and feedbacks will ultimately govern the evolution of a hydrogen-based transportation system, this initial modeling effort focused on the dynamic interdependence between hydrogen vehicle demand and hydrogen refueling station coverage. Further, a key element of this effort was the extension of MIT's one-dimensional spatial model 
of this interdependence [9] to a two-dimensional spatial model that could better represent realworld geographic and demographic variability. Other potential dynamics, such as

- the diffusion of technology awareness through experience and word-of-mouth;

- economies-of-scale and effect of experience on reducing manufacturing costs;

- technology performance improvements with time and research investment;

- growth of other complimentary infrastructure such as maintenance facilities;

- feedback of vehicle demand on resource availability and cost (e.g., natural gas and/or platinum);

etc., have not been included in this transition model but have been discussed elsewhere [9] [14], and/or will be considered for future model enhancements (see Section 9.0).

\subsection{Main Dynamics in HyDIVE}

\subsubsection{Overview: Positive and Negative Feedback}

The dynamics of any complex system are governed by two types of feedback, positive (or reinforcing) and negative (or balancing) [13]. In short, a reinforcing (or positive) feedback loop is one in which the increase in a particular parameter in the loop tends to lead to a further increase in that parameter through something akin to a "snowball" effect. Reinforcing loops tend to accelerate change and result in exponential growth in the absence of other counteracting forces. The classic example of a reinforcing loop is that of chickens laying eggs, which in turn hatch into chickens, which can then lay more eggs, and so on. Balancing (or negative) feedback loops, on the other hand, tend to counteract change. Balancing loops arise when an initial increase in one parameter in the loop tends to lead to a subsequent decrease in that same parameter, all else being equal. Continuing with the chicken and egg analogy, the more chickens that exist, the more attempted "road crossings" that will be attempted by the chickens (the reason the chicken crossed the road is left to the imagination of the reader!). Assuming some of those chickens don't make it across the road due to collisions with vehicles, these road crossings will tend to then decrease the chicken population. In the absence of other dynamics, a balancing loop will tend to result in an exponential decline of the parameters in the loop. The interaction of multiple reinforcing and balancing loops govern the behavior of any complex system. ${ }^{1}$

\subsubsection{Main Positive Feedbacks}

Figure 1 illustrates the main reinforcing (positive) feedbacks governing the system behavior of the HyDIVE model.

\footnotetext{
${ }^{1}$ For a more in-depth discussion of feedback, see reference [13], from which the examples described herein are drawn.
} 


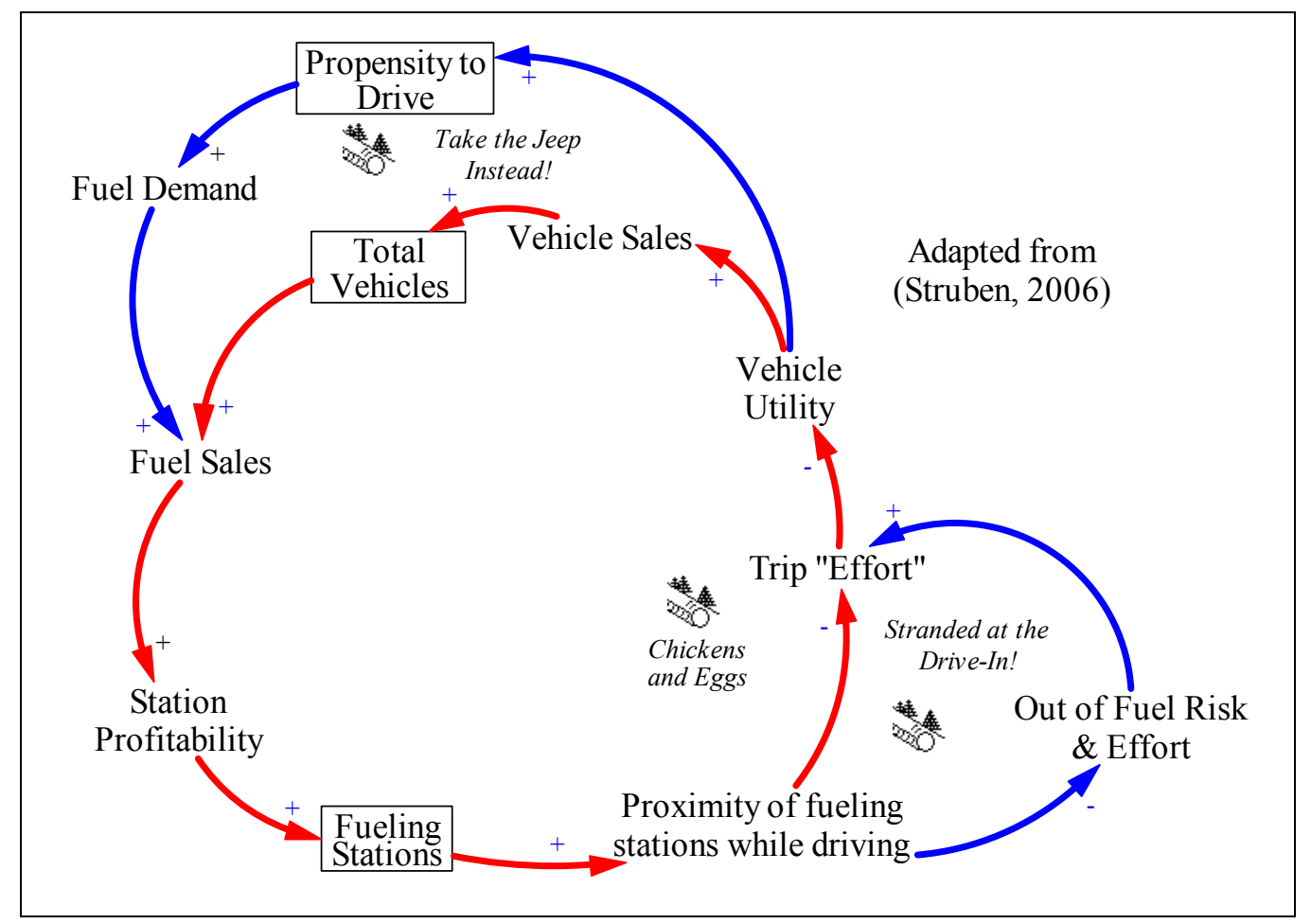

Figure 1: Main Reinforcing Feedbacks in HyDIVE. The growth of vehicle demand with increased fueling station coverage (and vice versa), the relative likelihood of running out of fuel (and its effect on vehicle sales), and the reduced propensity to drive at low levels of station coverage (which is a factor in station profitability) are all explicitly calculated.

\section{Reinforcing Feedback 1: "Chickens and Eggs"}

The first reinforcing feedback is the heart of the dynamic interdependence between refueling station coverage and vehicle demand. Consider first an increase in the number of alternative fuel stations (the Fueling Stations box in Figure 1). An increase in the total number of Fueling Stations will increase the Proximity of Fueling Stations While Driving (hence the positive "+" polarity on the connection between these two variables ${ }^{2}$.) As the Proximity of Fueling Stations While Driving increases, the required degree of Trip Effort will decrease (indicated by the negative " - " polarity on the connecting arrow). Trip Effort is explicitly calculated in HyDIVE using the local spatial distribution of refueling stations relative to potential vehicle purchasers and considering the desired driving patterns of vehicle owners (see Section 5.3.4). A decrease in Trip Effort serves to increase the Vehicle Utility, thereby increasing Vehicle Sales and Total Vehicles. As the number of Total Vehicles increases, so do the Fuel Sales, which will inevitably improve Station Profitability. The higher the Station Profitability, the greater is the likelihood

\footnotetext{
${ }^{2}$ If an increase in one variable has the direct effect of increasing the value of the connected variable (all else being equal), the polarity of the connection is positive, as indicated by a "+" sign on the connecting arrow. On the contrary, if an increase in one variable has the direct effect of decreasing the value of the connected variable (all else being equal), the polarity of the connection is negative, as indicated by a " - " sign on the connecting arrow.
} 
that other station owners will enter the market, which results in a further increase in the total Fueling Stations.

This reinforcing dynamic (sometimes referred to as a "virtuous cycle") has the potential to lead to an exponentially increasing number of alternative fuel vehicles and fueling stations. However, consider the case where Station Profitability is not positive. In this situation, stations would tend to close, leading to a subsequent decrease in Vehicle Utility. The resulting discards of the alternative fuel vehicles would then lower the Total Vehicles, Fuel Sales, and Station Profitability. Further station closures would then result, leading to another reinforcing dynamic, although this time operating as a "vicious cycle" rather than a virtuous cycle. A key determinant of whether this feedback will operate as a virtuous or a vicious cycle is whether sufficient demand for the alternative-fuel vehicles is induced by the existence of alternative-fuel stations to make the stations profitable.

\section{Reinforcing Feedback 2: "Take the Jeep Instead"}

The second key reinforcing feedback illustrated in Figure 1 addresses driver behavior once a consumer has actually purchased an alternative-fuel vehicle. If Vehicle Utility is low (e.g., resulting from few Fueling Stations and high Trip Effort), a driver can be expected to adjust his/her driving patterns accordingly. If, for instance, the Trip Effort is high for a particular trip, the driver may opt to "take the jeep instead." The likelihood of actually using the alternative-fuel vehicle, once purchased, is represented by the Propensity to Drive. In HyDIVE, the Propensity to Drive is also endogenously calculated based on the calculated Trip Effort, which is dependent again on local station coverage and desired driving patterns. Reduced Propensity to Drive (relative to the baseline of a gasoline ICE) lowers the Fuel Demand for the alternative fuel, affecting of course Fuel Sales and Station Profitability. Since an increase in Vehicle Utility serves to increase Propensity to Drive, Fuel Demand, and Fuel Sales this feedback also acts as a reinforcing dynamic similar to the "Chickens and Eggs" feedback discussed above. Including such a dynamic is important to account for reduced fuel sales relative to the baseline gasoline ICE at low levels of refueling station coverage, even once an alternative-fuel vehicle has been purchased. This dynamic also contributes to a "clustering" phenomenon, which is described further in section 8.0.

\section{Reinforcing Feedback 3: "Stranded at the Drive-In"}

The final reinforcing feedback illustrated in Figure 1 addresses the increased likelihood for a consumer to suffer the inconvenience of running out of fuel at low levels of refueling station coverage. An increase in the Proximity of Fueling Stations While Driving tends to decrease the Out of Fuel Risk and Effort, which also reduces overall Trip Effort, on average. This reduced Trip Effort then feeds the "Chickens and Eggs" positive feedback loop described above. The additional risk of running out of fuel, as well as the associated additional time and money of doing so, is explicitly calculated in HyDIVE. Incorporating this dynamic into a transition model is important since, at low levels of station coverage, the increased likelihood of running out of 
fuel is expected to have a significant impact on a consumer's likelihood of purchasing a vehicle as well as their likelihood of driving that vehicle once purchased.

\subsubsection{Main Negative Feedbacks}

In addition to the reinforcing feedbacks discussed in section 5.3.2, two main balancing feedbacks are incorporated into the model and illustrated in Figure 2.

\section{Balancing Feedback 1: "Supply Crowding"}

While an increase in the number of Fueling Stations helps to feed the virtuous cycle of the "Chickens and Eggs" feedback loop, it also has a counter-balancing effect that is seen through the Capacity Adequacy term in this loop. The Capacity Adequacy term in this loop is a representation of the total refueling station capacity relative to fuel sales. For a given level of Fuel Sales, having a larger number of stations means that more businesses are competing for the same fuel demand, which results in an increase in the Capacity Adequacy. To maximize profits, total station capacity should be close to fuel demand (not necessarily equal, as some buffer capacity is generally desired). Thus, an increase in Capacity Adequacy will reduce Station Profitability, which in turn will then tend to reduce the number of Fueling Stations, resulting in balancing feedback.

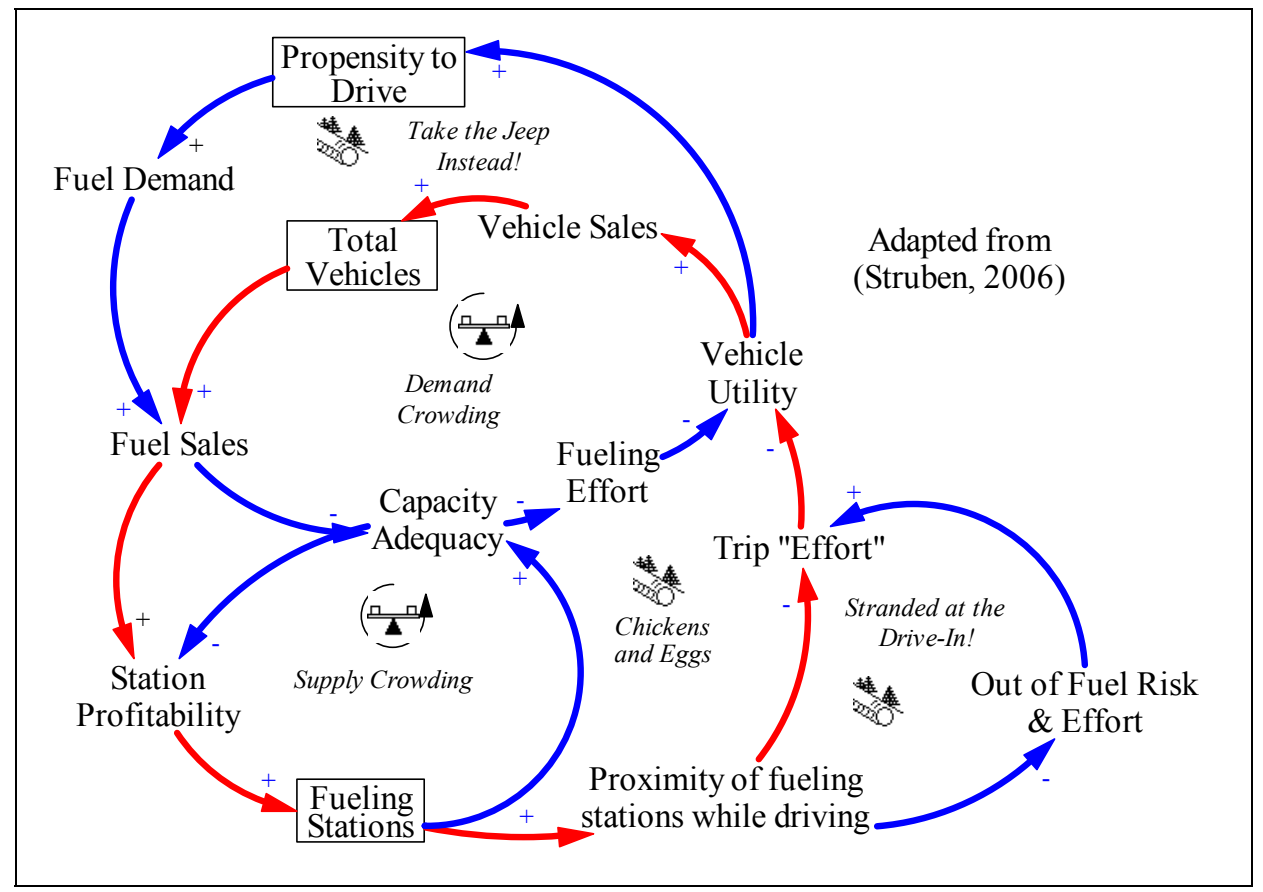

Figure 2: Main Reinforcing and Balancing Feedback in HyDIVE. In addition to the positive feedback described above, the model also calculates the effect of competition on station profitability ("Supply Crowding") and the effect of refueling time (including any "wait-time" due to queuing - a.k.a. "Demand Crowding") on vehicle utility and sales. 


\section{Balancing Feedback 2: "Demand Crowding"}

The last major feedback included in the current version of HyDIVE addresses the problem that would arise if Capacity Adequacy (as defined above) were too low. An initial reduction in Capacity Adequacy, for example, would increase the average queue of customers attempting to refuel their vehicles, since too many vehicle owners would be trying to use too few refueling stations. An increase in the average customer queue results in longer average wait times for vehicle owners to refill their vehicles. This additional wait time effectively increases the Fueling Effort, which tends to decrease Vehicle Utility. Through the mechanism described in section 5.3.2, this decrease in Vehicle Utility would then reduce both the Propensity to Drive and the Total Vehicles on the road, thereby reducing Fuel Sales. This reduction in Fuel Sales then increases the Capacity Adequacy, serving to offset its initial reduction, resulting in a balancing feedback. Of course, the opposite would occur with an initial increase (rather than decrease) in Capacity Adequacy.

\subsubsection{Spatial Interdependence between Vehicle Demand and Station Coverage}

As mentioned in Section 5.2, a focus area of this initial modeling effort was to extend the onedimensional model developed by MIT [9] to a two-dimensional spatial model. The rationale for this focus was that the demand for alternative-fuel vehicles is expected to be spatially nonhomogeneous and dependent on local refueling station coverage relative to potential vehicle purchasers and desired driving patterns. This notion of a spatially non-homogeneous alternativefuel vehicle market is supported by inspection of the spatial distribution of existing alternativefuel stations, as found in the Alternative Fuels Data Center [4]. Further, one component of ongoing discussion and debate regarding the most effective strategy for introducing hydrogen vehicles is the best way to spatially distribute initial refueling stations. Thus, analysis methods that explicitly address the interdependence between vehicle demand and refueling station coverage should help to shed light on this transition strategy issue. ${ }^{3}$ Some analyses have considered linking at a high level refueling station coverage with vehicle demand [5], and other analyses have investigated the effect of spatial station coverage on driver convenience (such as by calculating the average time to the nearest refueling station) [15], but HyDIVE appears to be the only model that addresses both the spatial element of refueling convenience and the link between that convenience and vehicle demand, especially in a dynamic manner.

Figure 3 illustrates at a high level the spatial interdependence of vehicle demand, station profitability, and refueling station coverage that is included in HyDIVE. Consider a particular level of vehicle demand, located spatially in cell c. Owners of alternative fuel vehicles in cell c will travel both within cell $\mathrm{c}$ and beyond cell c (for instance into cell c'). The current simulations assume a radially symmetric log-normal trip distribution frequency, as illustrated by the shaded curve originating at the center of cell c. Travel to cell c', for example, contributes to fuel demand in cell c', which improves station profitability there. As described in Section 5.3.2, increased

\footnotetext{
${ }^{3}$ For elaboration of the significance of including a spatial component in this dynamic model, see reference [14].
} 
station profitability tends to result in a greater number of stations in cell c', which also has the effect of reducing the trip effort for vehicle owners in cell c, since they also travel into adjacent cells. This reduced trip effort increases vehicle utility and therefore vehicle demand back in cell c. Through this spatial interdependence, vehicle demand in one cell contributes to station profitability in adjacent cells. Likewise, station coverage in one cell contributes to vehicle demand in adjacent cells by improving the overall convenience of refueling.

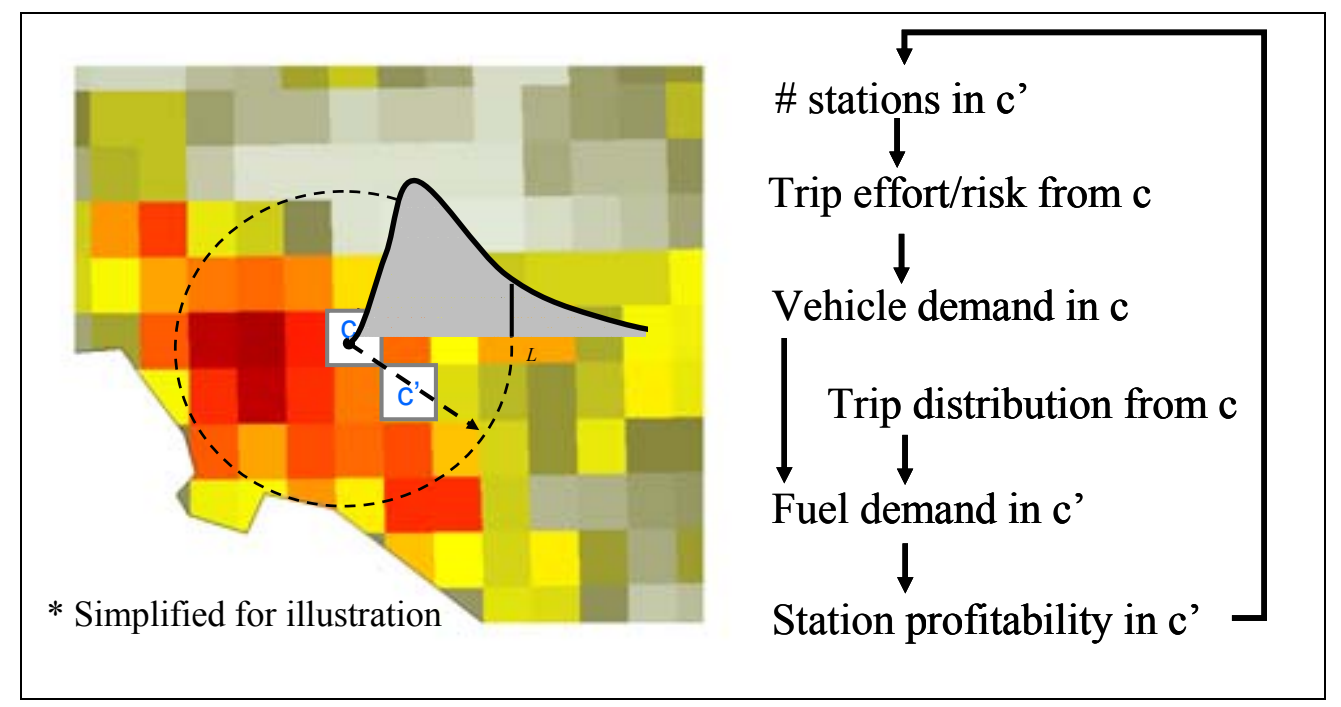

Figure 3: Illustration of Spatial Interdependence of Vehicle Demand and Refueling Station Coverage. Vehicle demand in cell $c$ is affected by refueling station coverage in cell $c^{\prime}$ (and other adjacent cells). Likewise, station profitability and quantity in cell $c^{\prime}$ is affected by vehicle demand in cell $c$ (and in adjacent cells). A radially symmetric log-normal driver trip distribution frequency

is currently assumed (shaded curve). The dynamic, spatial interaction of these variables, combined with other dynamics, will govern the evolution of a hydrogen-based transportation system. Figure adapted from reference [16].

\subsection{Key Model Inputs}

Although a detailed listing and formulation of the variables included in HyDIVE is beyond the scope of this report, some of the more significant model inputs are listed in Figure 4. Consistent with the cross-disciplinary nature of System Dynamics, HyDIVE includes economic, technological, and behavioral inputs for both the supply side (i.e., refueling stations) and the demand side (i.e., vehicle and fuel purchases). Illustration of the key spatial data input is provided in Figure 5. Other spatially distributed data (e.g., detailed driving patterns) could also be incorporated into this type of model. However, comparison of the value added by additional spatial data with the inevitable increase in model run-time and memory requirements would be required to evaluate the efficacy of additional spatial complexity. 


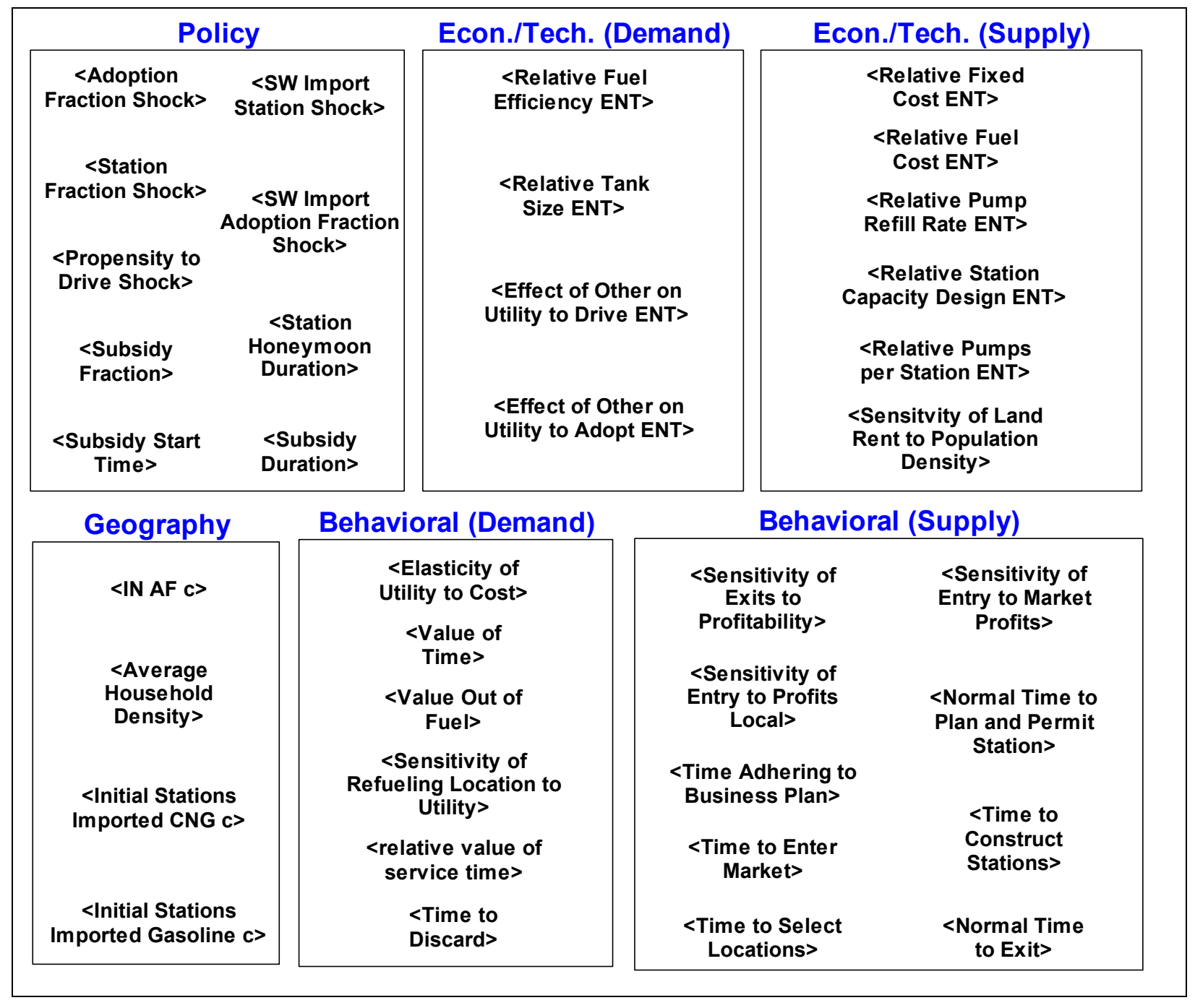

Figure 4: Example Model Inputs - Model Input Page. Technical, economic, and behavioral inputs are gathered for both the supply side (i.e., refueling stations) and the demand side (i.e., vehicles). Additionally, incentives/policies can be simulated. Figure adapted from reference [10]. 


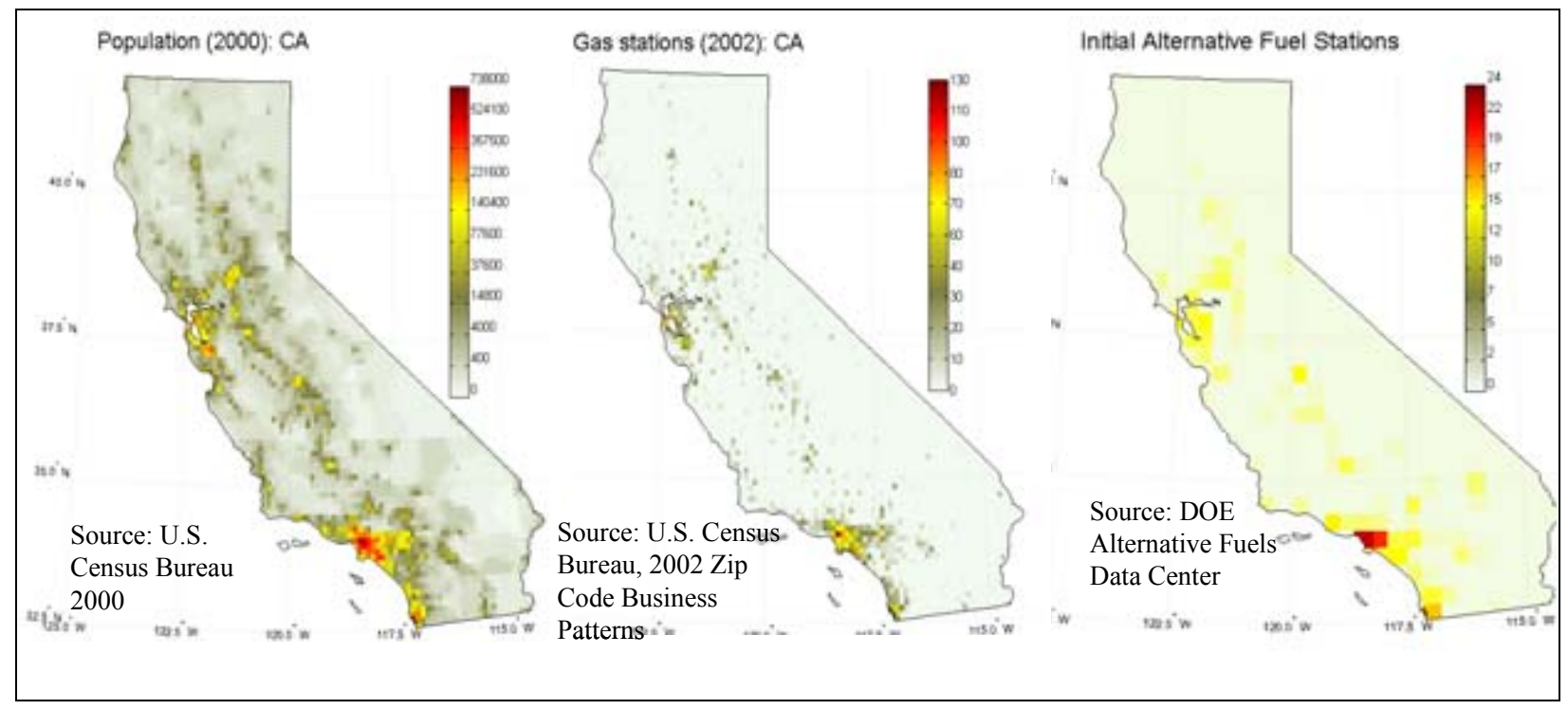

Figure 5: Example Spatial Data Input [17] [18] [4].

\subsection{Preliminary Simulations and Model Output}

Although HyDIVE is still under development, example simulations were run to illustrate model output, insights, spatial and dynamic behavior, and model sensitivities. Model output variables are qualitatively illustrated to convey behavior and dynamics rather than absolute values. Since California is aggressively pursuing alternative-fueled and environmentally-friendly vehicles, it is expected to be at the forefront of any attempted introduction of hydrogen-powered vehicles (e.g., fuel cells). Thus, initial modeling efforts focused on California, although the methodology could be applied to any state or region. Attempts to introduce compressed natural gas vehicles in California are analogous to future attempts to introduce hydrogen-powered vehicles in that a refueling infrastructure delivering a gaseous fuel must be installed to support the alternativefueled vehicle. Thus, compressed natural gas infrastructure and vehicle users were used as inputs for this initial modeling effort.

\subsection{Simplified Case Study Assumptions and Inputs for Illustrating Model Behavior}

Assumption 1: As illustrated in Figure 6, an initial market "seed" of 24,990 total CNG vehicle users [19] and 216 total CNG refueling stations [4] were used as inputs to the model. These values represent the status of CNG vehicle adoption and station coverage in the year 2002 . Spatial distribution of the refueling stations is consistent with the recorded latitude and longitude of CNG stations in the Alternative Fuels Data Center [4]. Spatial distribution of CNG vehicles is not known, however. Thus, the model simulated an optimal spatial distribution consistent with maximizing the "utility to drive" for the given spatial distribution of refueling stations. 


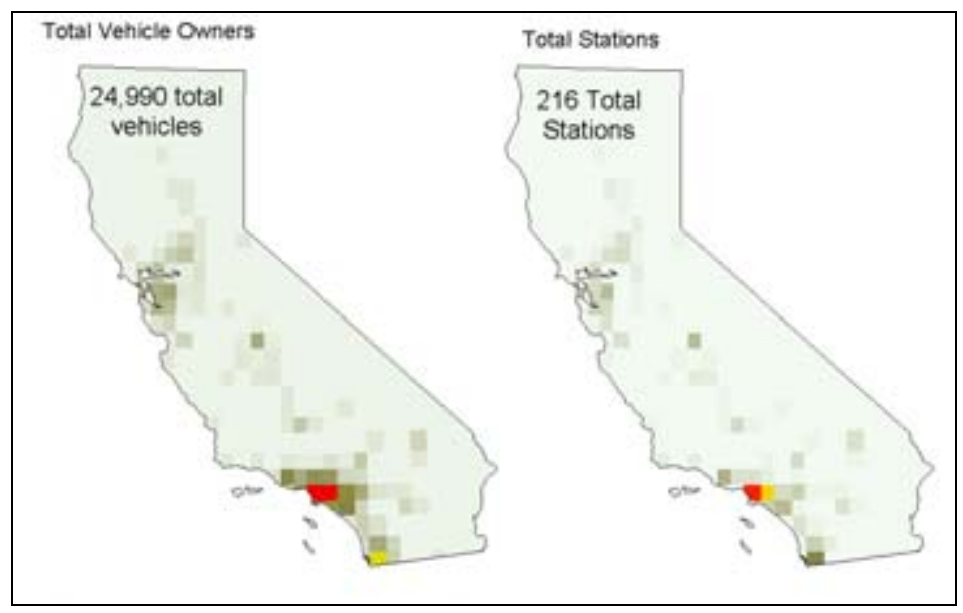

Figure 6: Initial Adoption Fraction and Refueling Stations. The total number of CNG refueling stations in 2002 [4] and the estimated total CNG vehicles in use in California in 2002 [19] were used as example market "seeds" to illustrate model behavior.

Assumption 2: To isolate the infrastructure availability/vehicle demand interdependence, vehicle cost and performance as well as refueling station and fuel costs were input as being the same for gasoline vehicles/stations and the alternative fuel vehicles/stations. Additionally, this model run initially assumes that consumers are both aware of and have access to every refueling station. We know that much of the deployment of natural gas vehicles has been with fleets, not consumers, so that many refueling stations are not accessible to the public (see Section 8.3), but this assumption is made anyway for illustration purposes. Further analyses combined with model extensions (e.g., incorporation of an "awareness" feedback loop) could certainly relax these assumptions.

Assumption 3: To understand and illustrate market-driven dynamics, we assumed that all refueling station owners follow rational business decision making processes and seek profitability. Further, we assumed that desired vehicle driving trip distributions and refueling patterns and behaviors are consistent with those of a typical consumer, as opposed to those of fleet operators, as well as spatially homogeneous (an assumption that could also be relaxed).

Assumption 4: Finally, to illustrate the dynamics of refueling station and vehicle demand growth (as compared with collapse), we assumed that consumers have a relatively low sensitivity to (i.e., a high willingness to accept) the additional driving effort and risk (which are endogenously calculated in the model) associated with limited station coverage. Model output sensitivity to changes in this input parameter (consumer sensitivity to driving effort and risk) will be illustrated in Section 6.3.

Assumption 5: To prevent immediate closures of unprofitable stations, we assumed that any station financial losses are fully subsidized for a period of 6 years after start of the model run. 


\subsection{Example Model Output and Behavior}

Figure 7 and Figure 8 illustrate the endogenously calculated, spatially distributed growth of refueling stations resulting from the inputs and assumptions described in Section 6.1. As can be seen in Figure 8, refueling stations remain open in the early years since any station losses are fully subsidized. Due to the assumption of low consumer sensitivity to additional driving effort and growth (and due to the assumption of vehicle cost/performance parity), some additional consumers purchase the alternative-fueled vehicles, which drives demand for fuel and further station openings to meet that local demand. Later, upon expiration of the subsidy (around year 6), unprofitable stations close, primarily in the more rural regions where the frequency of travel is lower (see Figure 7), contributing to the lack of station profitability. Station growth continues, however, in the more densely populated regions of the state, driven by growth in vehicle demand and the interdependent, reinforcing feedback loop described in Section 5.3.2. Finally, it should be noted that market forces result in a final station coverage that is "clustered" around the population centers, with few or no stations remaining open in the more rural areas of the state. This "clustering" phenomenon and its implications are discussed in more detail in Section 8.0.

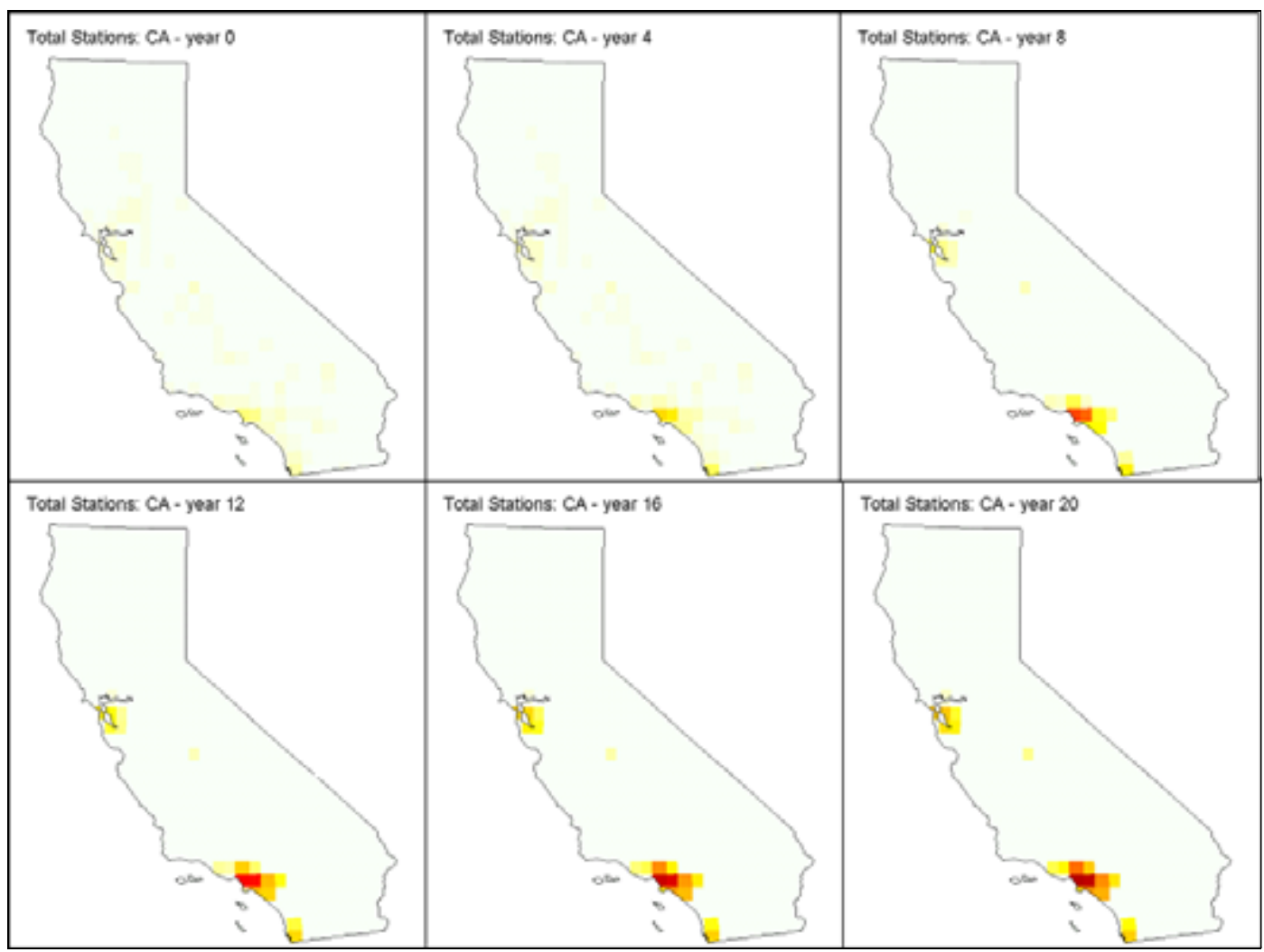

Figure 7: Spatial Growth of Refueling Stations. Initially, refueling stations existed in both metropolitan and rural areas. Upon removal of simulated station subsidies, however, the more rural stations would be projected to close due to lack of profitability. Understanding the "clustering" phenomenon (near metropolitan areas) illustrated by this output can inform the comparison of various hydrogen transition and infrastructure introduction strategies. 


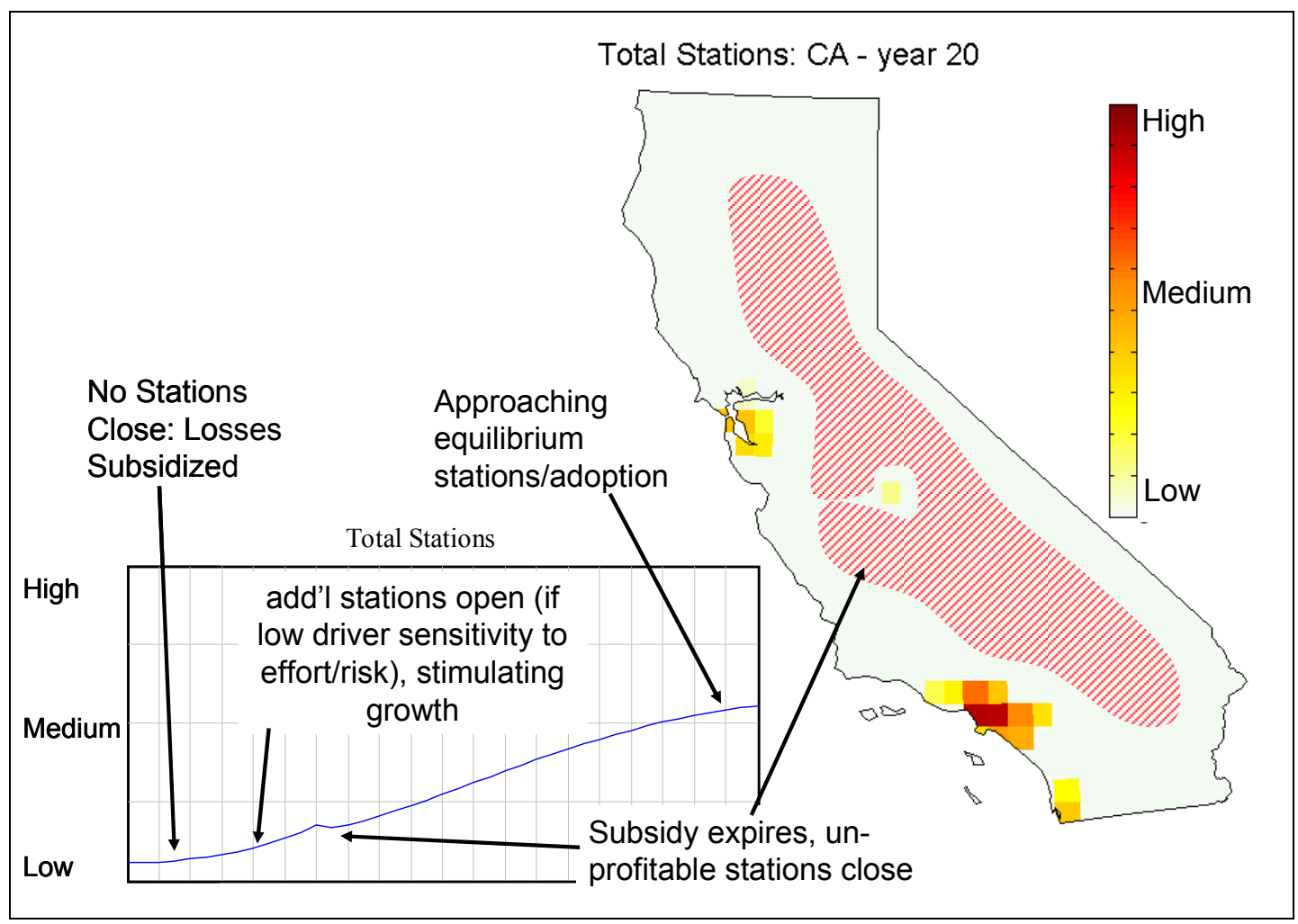

Figure 8: Model Output - Total Refueling Stations vs. Time. High station subsidies combined with the initial assumption of low consumer sensitivity to additional effort/risk associated with low station coverage contributes to initial growth. Equilibrium market penetration is still less than that of the status quo (gasoline ICE's) due to a high degree of "clustering" near metropolitan centers, which limits diffusion of the technology even under assumptions of vehicle/fuel performance and cost parity.

Figure 9 and Figure 10 illustrate the endogenously calculated, spatially distributed, adoption fraction of alternative-fueled vehicles. As can be seen in Figure 10, the adoption fraction rises sharply in the early years due to the simplifying and illustrative assumptions of 1) vehicle cost and performance parity with conventional gasoline ICE's and 2) low consumer sensitivity to additional driving effort and risk of low station coverage. Additionally, other dynamics that would inevitably slow vehicle adoption (e.g., "awareness" through word-of-mouth, etc.) have not yet been incorporated. This initially rapid rise in adoption fraction implies that for the initial level of station coverage, more consumers would choose to purchase the alternative-fueled vehicle than the initial input value of 24,990 vehicle owners. Again, the assumption of low consumer sensitivity to additional effort and risk of low station coverage is later relaxed, with the effects illustrated and discussed in Section 6.3. Next, we see that while the adoption fraction continues to grow in the metropolitan areas, it declines in more rural areas as consumers discard their vehicles (Figure 9) because, as discussed above, stations closed in these areas for profitability reasons once the subsidy expired (in year 6). Finally, similar to the equilibrium spatial distribution of refueling stations, the adoption fraction in more rural areas is low or zero, 
but is higher in the more metropolitan areas due to a "clustering" effect resulting from the local interdependence between vehicle demand and station profitability. Although not quantified in Figure 9, equilibrium market penetration is lower than the status quo (gasoline ICE's) due to a high degree of "clustering" near metropolitan centers, which limits diffusion of the alternative technology even under assumptions of vehicle/fuel performance and cost parity. Again, refer to Section 8.0 for more discussion regarding this "clustering" phenomenon.

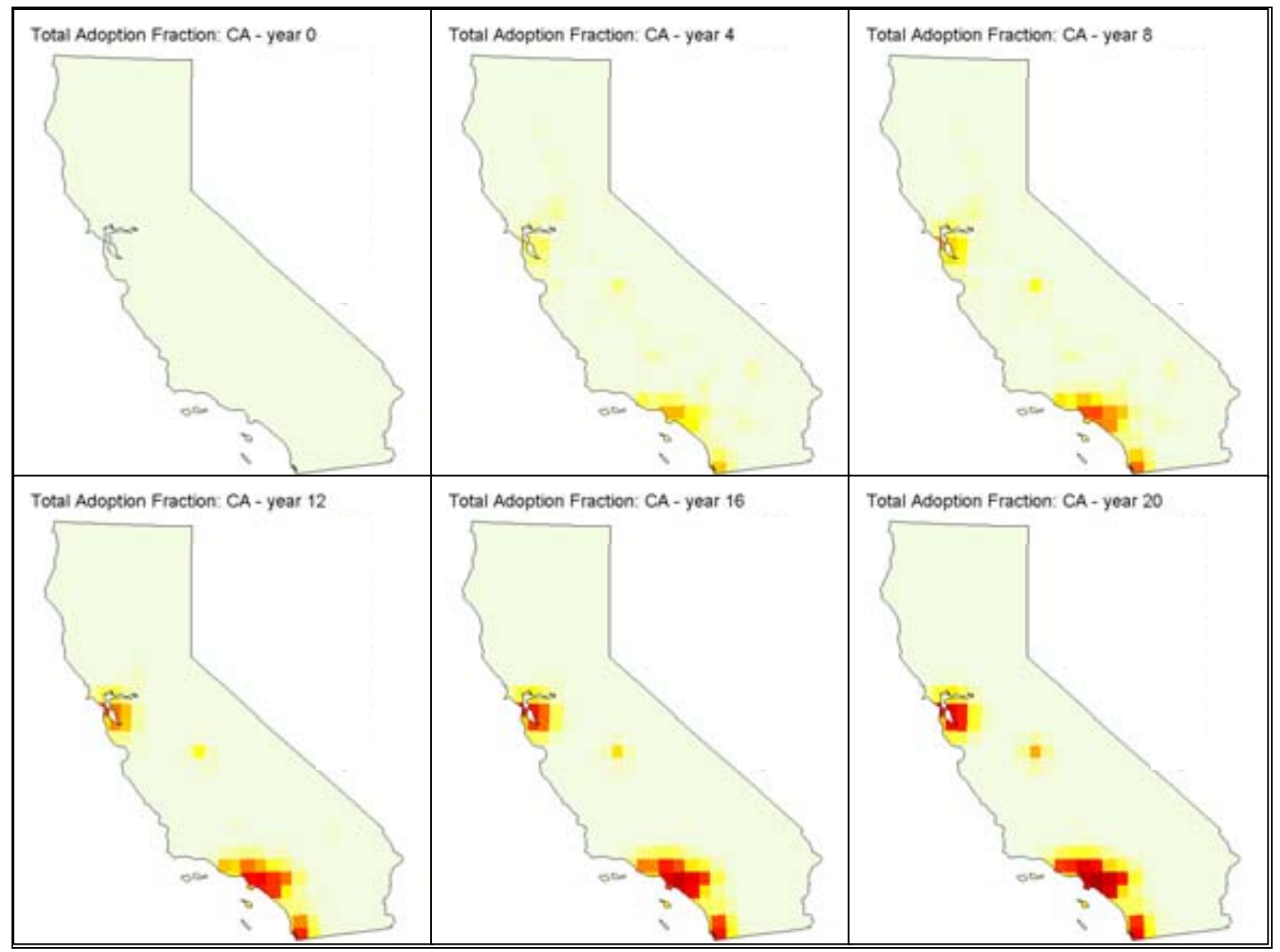

Figure 9: Spatial Growth of Adoption Fraction. Spatial distribution of Adoption Fraction (i.e., fraction of population owning an alternative-fuel vehicle) is similar to that of the distribution of refueling stations. Under the initial illustrative assumptions, the market fails to penetrate into the more rural areas, remaining "clustered" near the metropolitan regions. 


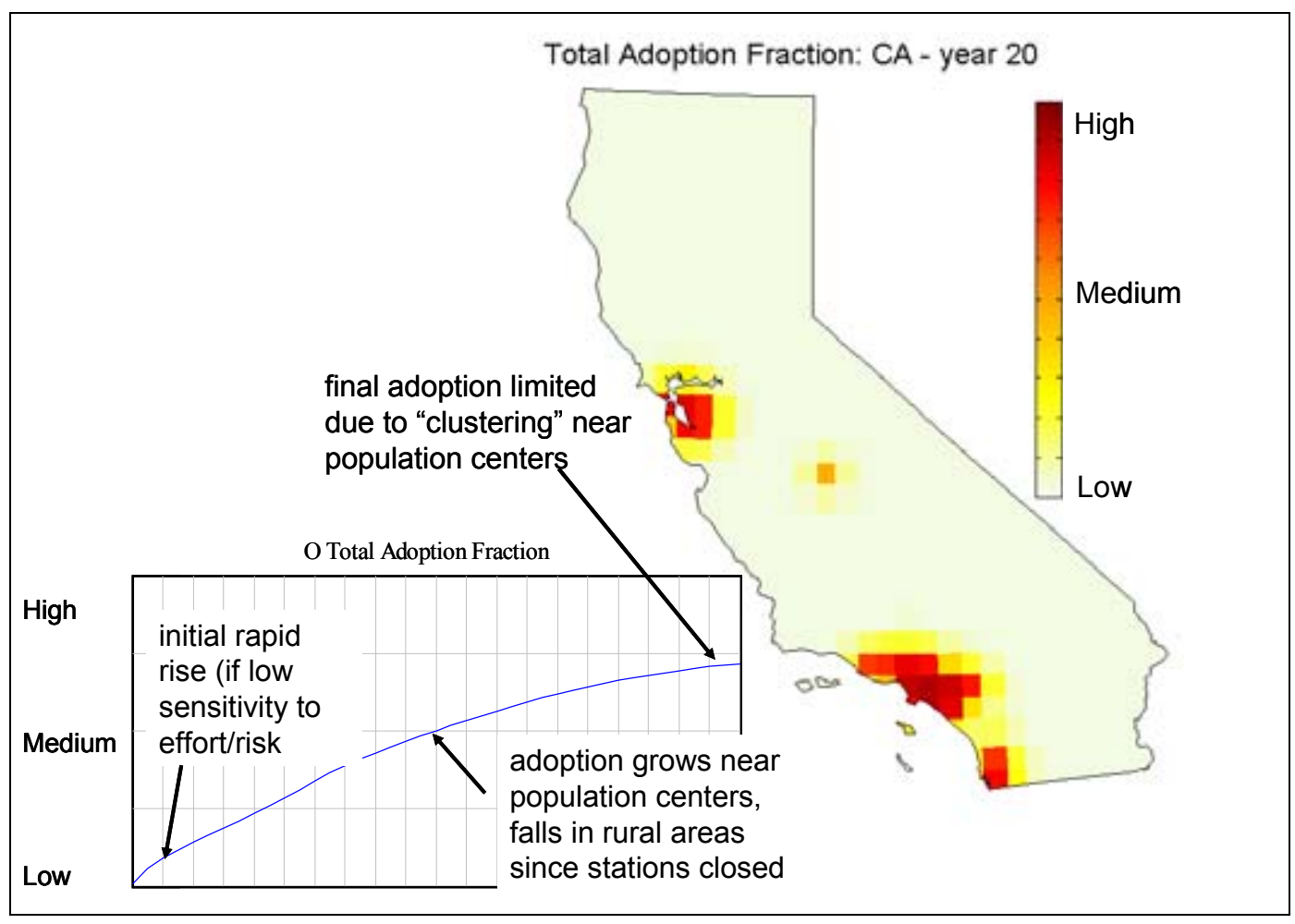

Figure 10: Model Output-Vehicle Adoption Fraction vs. Time. An initially rapid rise of vehicle adoption results from assuming low consumer sensitivity to additional effort/cost associated with low station coverage. Additionally, other dynamics that would inevitably slow vehicle adoption (e.g., "awareness" through word-of-mouth, etc.) have not yet been incorporated. As with refueling station coverage, vehicle adoption fraction is clustered near the metropolitan areas. This clustering contributes to a final equilibrium adoption fraction that is lower than the status quo (gasoline ICE), even under assumptions of vehicle/fuel performance and cost parity.

\subsection{Model Sensitivity}

The analysis described in Section 6.2 assumed that consumer sensitivity to additional driving effort and risk is somewhat low. Such an assumption, combined with assumptions regarding vehicle/station cost and performance parity, resulted in a growing alternative-fuel-vehicle market. However, it seems likely that consumers have become quite accustomed to the high level of convenience afforded by the ubiquitous nature of gasoline stations. Very little, if any, planning is currently required to ensure the ability to fuel a vehicle with gasoline. Any departure from complete refueling station coverage results in additional planning and/or travel time for a consumer as well as additional risk of running out of fuel. Because consumers place a value on their time (whether consciously or unconsciously), these inconveniences effectively increase the "cost" of purchasing and operating an alternative-fueled vehicle. The degree to which consumers will be sensitive to this additional cost of an alternative-fuel-vehicle is not well understood, yet it 
can have significant impact on whether an attempt to introduce an alternative-fuel vehicle will be successful.

Figure 11 illustrates, for example, the effect on the total fraction of consumers purchasing an alternative-fuel-vehicle (Total Adoption Fraction) at different levels of consumer sensitivity to additional effort and risk. At low consumer sensitivity ${ }^{4}[20]$, as indicated by the blue line in Figure 11, total adoption fraction rises rapidly initially and then equilibrates. However, for a high consumer sensitivity, as indicated by the green line in Figure 11, the quantity of vehicle adopters was insufficient to result in local station profitability. Thus, a downward spiral of station closings and alternative-fuel-vehicle discards results in a collapse of the market when the station subsidy expires in year six.

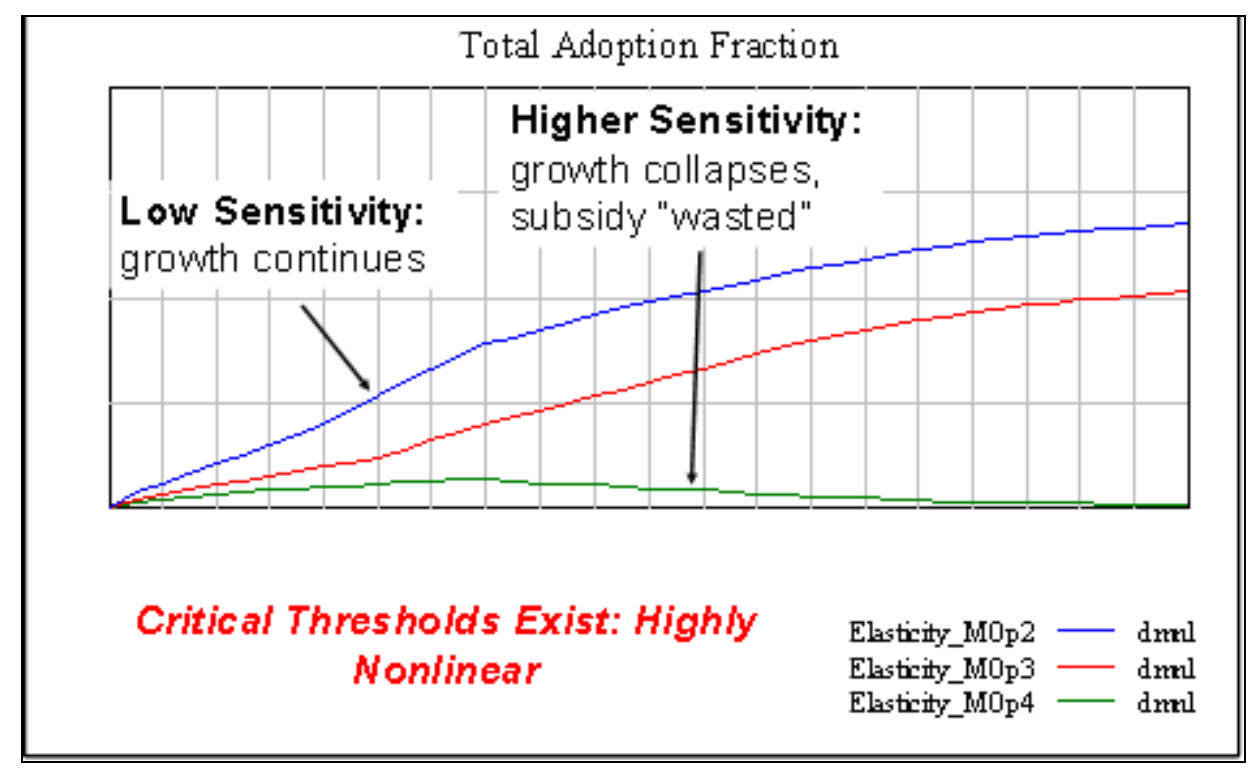

Figure 11: Effect of Consumer Sensitivity to Additional Driving Effort and Risk on Total Adoption Fraction.

The above example illustrates a "tipping point" phenomenon that exists in this complex, dynamic system. Highly non-linear thresholds exist where modest changes in certain parameters can result in markedly different system behavior. In the above example, this "tipping point" resulted from changes in the assumed consumer sensitivity. However, similar tipping points would also exist for many other model parameters. For instance, Figure 12 illustrates a similar phenomenon for different levels of station subsidy. At high station subsidy levels, the market continues to grow even upon removal of the subsidy, but at lower levels of station subsidy, the market collapses

\footnotetext{
${ }^{4}$ In HyDIVE, consumer sensitivity to additional driving effort and risk is modeled with an elasticity parameter $\dot{\varepsilon}$, which is defined as the fractional change in utility (a dimensionless input to a standard multinomial logit "choice" function) divided by the fractional change in the net cost of a "trip." Additional time required to travel is explicitly calculated and translated into dollars using an assumed dollar value of time, in this case \$40/hr (reference 20). For more detail, see reference 14 .
} 
upon removal of the subsidy because the initial subsidy was insufficient to achieve the "critical mass" of vehicles and stations required for the market to be self-sustaining upon removal of the subsidy.

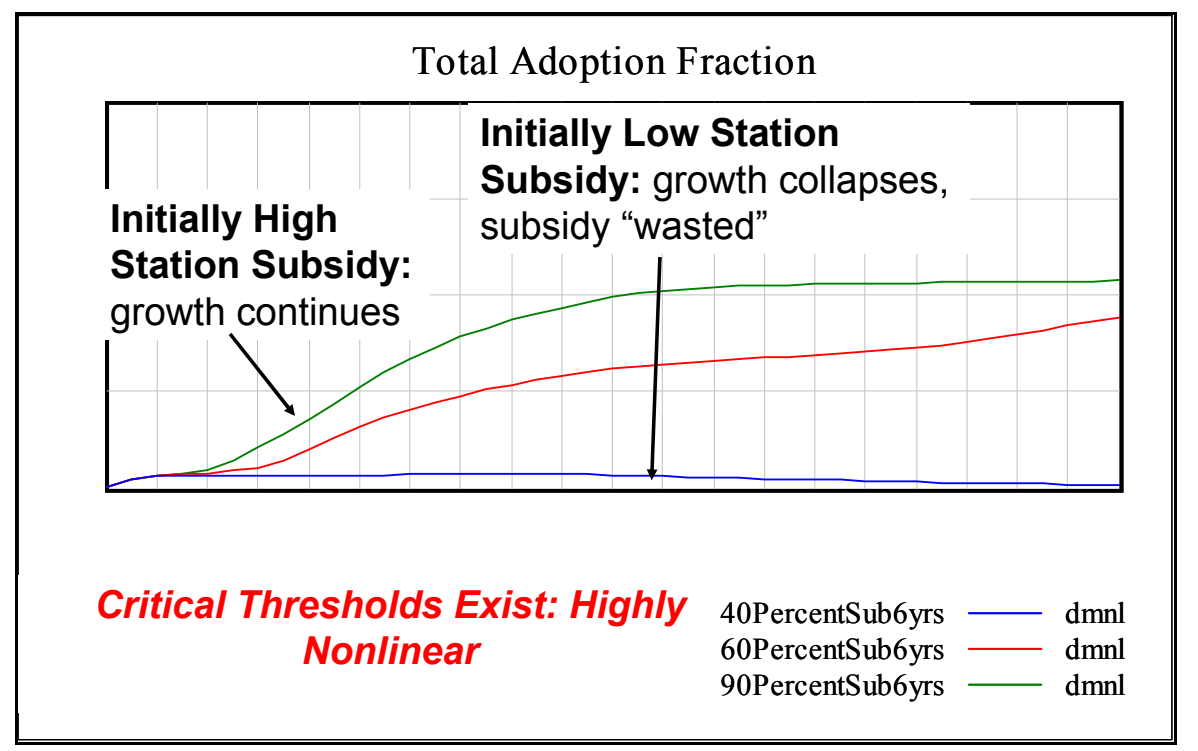

Figure 12: Sensitivity of Total Adoption Fraction to Percent Station Subsidy.

\subsection{Data}

One of the objectives of this project was to identify the necessary data for the transition model(s) under review, to gather and provide data where possible, and to identify any data gaps. Early in this project, key data needs were identified that could be met relatively easily. For instance, as identified in Figure 5, spatial data regarding population [17], existing gasoline stations [18], and existing CNG stations [4] were used as inputs to the dynamic model. Additionally, we identified the Alternative Fuels Data Center (AFDC) [4] as a source of additional information that could be valuable for model development and validation activities. When properly queried, the AFDC could provide both spatial and temporal information about the existence of alternative-fuel stations. This information could be used as a comparison against model output for validation purposes, although this detailed validation was not conducted as part of this project. The AFDC also contains information on state and federal incentives/laws, availability of alternative fuel vehicles, and accessibility of alternative-fuel stations--an important variable to consider for initial conditions of the model (see Figure 13 for an example). Additionally, data on total alternative-fuel vehicles estimated to be in use over time were readily available from the Energy Information Administration [19]. Finally, studies on the value consumers place on their time while driving were identified and used as model inputs [20].

This initial data gathering was useful and facilitated initial model runs; however, additional data would be required to improve confidence in model output. As provided in accordance with the 
subcontract [11], Appendix 1 illustrates the more significant data needs required to support thorough model development and validation. Some of the data in Appendix 1 may be readily available, but has not yet been collected, whereas other data may require additional research.

Although comprehensive sensitivity testing of HyDIVE has not yet been performed to identify the parameters most in need of refinement, one parameter in particular has stood out for its ability to influence system behavior: "Elasticity of Utility to Cost." This elasticity parameter is defined as the fractional change in utility (a dimensionless parameter input to a standard multinomial logit "choice" function) to drive (or to purchase a vehicle) divided by the fractional change in "cost" (including actual dollar costs as well as additional time, which is translated into a dollar value). The extent to which consumers will be sensitive to the additional costs (e.g., time, money, risk, etc.) associated with purchasing and driving an alternative-fuel vehicle is highly uncertain, but will have a large impact on where the "tipping point" is for this dynamic system. Considering the uncertainty of this parameter combined with its high potential impact on the success or failure of any transition strategy, additional research in this area seems warranted.

\subsection{Insights}

The methodology of System Dynamics has the benefit of forcing stakeholders and modelers to think about a complex problem in ways they might not have in the absence of rigorous modeling of a complete system. The effects of the inevitable interdependencies, feedbacks, and delays in any complex system are often not intuitively obvious at the outset. Even before a System Dynamics model has been developed to the point where a high degree of confidence exists in the model output, insights are gained into the workings and behavior of a complex system. This section discusses three of the more significant insights gained during the early stages of this modeling effort. ${ }^{5}$

\subsection{Tipping Points}

Section 6.3 introduced the concept of "tipping points," or the existence of critical thresholds that, if exceeded, would permit self-sustained growth of alternative-fuel station coverage and vehicle demand. On the contrary, if the initial "push" of the technology (e.g., via government incentives, subsidies, tax credits, etc.) is insufficient to cross that tipping point, it is possible for the market to collapse, potentially wasting billions of dollars in government and private investment. The mere existence of these highly nonlinear tipping points has implications for technology policy. A better understanding of the magnitude and duration of incentives required to support a hydrogen transition is critical to ensure all relevant technology and policy options are considered.

For instance, consider the following potential scenario. If consumers place a high enough value on their time and on the convenience of refueling (or if technology performance and/or cost does not improve as much as anticipated), it is quite possible that government subsidies would be

\footnotetext{
${ }^{5}$ See reference 12 for additional discussion of initial modeling insights.
} 
required for decades (or until crisis events such as skyrocketing gasoline prices occur) to prevent market collapse due to insufficient fuel and/or vehicle sales. Under such a scenario, the level of risk and magnitude of investment may be such that taxpayers and legislatures are unwilling to support the transition in the absence of a crisis. Under this scenario, alternate technology options may be considered. Some companies (e.g., BMW, Mazda) have gone so far as to advocate, for instance, bi-fuel hydrogen/gasoline internal combustion engines, arguing that these bi-fuel vehicles could permit a build-up of hydrogen stations to the point where a hydrogen-only vehicle would be more palatable to an average consumer. Although more comprehensive analysis and further modeling would be required to better compare the merits of a "bi-fuel" vs. "directhydrogen" transition strategy, the "bi-fuel" option is one example of an alternative that might be considered if the tipping point for a direct-hydrogen transition is revealed to be unacceptably high.

While a dynamic model incorporating technological, economic, and behavioral parameters could help quantify these tipping points, uncertainty about the required level and duration of government incentives, technology performance, and costs is inevitable. However, rigorous dynamic modeling could facilitate the development of transition strategies and policies that are robust in light of this inevitable uncertainty.

\subsection{Clustering}

Section 6.2 alluded to a system behavior (as identified through dynamic modeling) of "clustering," whereby refueling stations and vehicle demand tend to concentrate near metropolitan areas. Another way to think of this phenomenon is that metropolitan areas have a lower tipping point (Section 8.2) than do more rural areas, which also has implications for transition strategies and policies. Before considering the implications for strategy, however, let us first consider the driving factors for this clustering mechanism.

First, recall from Figure 3 that driver trip distributions tend to follow a log-normal behavior, where a larger percentage of trips are taken closer to a vehicle owner's residence, and a smaller percentage of trips are taken farther away. The shape of a driver's trip distribution function is important in determining how easily fuel demand will "diffuse" into areas far removed from a vehicle owner's home. In general, the larger the percentage of trips taken closer to a vehicle owner's home, the more difficult it will be for stations far from a vehicle owner's home to become profitable. Such driving patterns contribute to a lower "tipping point" (i.e., greater ease of refueling station profitability) in regions closer to vehicle owners' homes (i.e., in major metropolitan areas).

Second, refueling station owners can be expected to make decisions based on expectations of future profit. One factor contributing to whether a refueling station will open is potential market size. The larger the potential market, the greater risk a business owner is generally willing to take in hopes of capturing sales in that market. Since the potential market for hydrogen vehicles (and the associated hydrogen fuel), for example, is largest in areas of high population, station owners can be expected to be more willing to take the risk of opening a new refueling station in these 
areas. This "potential market" mechanism also contributes to a clustering of refueling stations and vehicle demand in metropolitan areas.

Finally, recall from section 5.3.2 the "take the jeep instead" dynamic. Even once a consumer has purchased an alternative-fuel vehicle, he/she will still make decisions about whether to use that vehicle for a particular trip. These decisions will depend on the expected effort and risk associated with making that trip for the given level of refueling station coverage. At low levels of station coverage, drivers will be less willing to take longer trips due to the greater probability of running out of fuel and/or the additional effort required to refuel during that trip. This dynamic has the effect of shifting the trip distribution frequency for alternative-fuel vehicle owners toward having a higher percentage of trips closer to home. For the same reasons described above, this has the effect of making it more difficult for stations far from a vehicle owner to be profitable in the early stages of a transition.

The clustering behavior described above has the following strategy/policy implications. Governments and industry would presumably like to invest in high cost and high risk refueling infrastructure in areas where it will most likely succeed initially. Such initial successes will be necessary for continued industry, government, and taxpayer support of any new, unfamiliar, and largely unproven technology. Considering the lower tipping point in metropolitan areas due to the clustering mechanism described above and in the model simulations of Section 6.2, it seems that establishing a "critical mass" of hydrogen refueling stations in major metropolitan areas, which could later be linked together, might have a higher probability of success than would a strategy of beginning with a "hydrogen highway." It is not as much a question of whether a hydrogen highway network should be supported (e.g., through government investment) as it is when this investment should take place. Some level of government incentive is likely going to be required in both urban and rural areas in the initial stages of a transition. But since urban areas seem to have a lower tipping point than do rural areas, for the reasons described above, it seems prudent to start with an investment in those areas. This approach of starting in metropolitan areas and later linking them is also recommended in a static spatial analysis of hydrogen refueling infrastructure performed by UC Davis [15]. Further spatial dynamic analyses, particularly if additional spatial detail regarding consumer driving patterns were incorporated, could further elucidate this issue.

\subsection{Fleet vs. Consumer-Driven Approach}

Previous alternative-fuel vehicle attempts focused largely on a "fleet" approach. For example, the Energy Policy Act of 1992 [1] mandated the acquisition of an increasing percentage of alternative-fuel vehicles by federal and state fleets and alternative fuel providers. Such acquisitions were intended to create a seed for the development of an alternative fuel market by stimulating the production and purchase of alternative-fuel vehicles, thereby creating a demand 
for the alternative fuel. ${ }^{6}$ In the initial stages of introduction for any alternative fuel, fleet markets have some advantages that make them attractive as market seeds. One advantage is that fleet vehicles tend to be able to refuel in a centralized location (as compared with average consumers, who require a large number of geographically dispersed refueling stations), making it easier to create a supportive fueling station infrastructure. Additionally, it is easier for the government to mandate fleet vehicle acquisitions than to mandate acquisitions for more typical vehicle consumers. However, previous attempts at introducing alternative-fuel vehicles have not been very successful, if success is measured for instance by displacement of petroleum. Thus, many in the hydrogen arena are now advocating a more "consumer-driven" approach, whereby the mass market is targeted rather than fleets.

To better understand these approaches, let us first consider a few additional insights gained from this modeling activity. The "take the jeep instead" dynamic discussed in Section 5.3.2 reminds us that initial fuel sales per vehicle are likely to be lower than for a conventional gasoline ICE since some fraction of trips will be too difficult to make due to low initial station coverage. Unfortunately, this dynamic has the impact of making station profitability more difficult, as an even greater ratio of vehicles to stations would be required for a comparable level of station operating costs. To help overcome this profitability problem, one introduction strategy might be to initially target high fuel usage vehicle owners. If a particular fleet satisfies this high fuel usage criterion, it may reduce the time and investment required to achieve station profitability and therefore a self-sustaining market, although further analysis would be required for quantification.

However, a primarily fleet-driven approach must consider what mechanisms would contribute to eventual "spillover" into a mass market. The author would argue, for instance, that for a station to be considered a seed for a consumer market, the average consumer must both be aware of the station (or have the ability to become aware easily) and have access to it. As noted above, a fleet is potentially easier to support with fueling infrastructure since fleet vehicles are more likely to be able to refuel in a centralized location. Unfortunately, this advantage (enjoyed by fleets in the early stages of a transition) can also be a disadvantage for eventual spillover into a mass market. For fleet refueling to be convenient for fleet operators, the stations tend to be located in industrial or government facilities and may not be accessible to the average consumer. Figure 13 illustrates, for instance, that nearly half of the 216 CNG stations in California in the year 2002 were not accessible to the general public. Additionally, of those that are accessible to the public, more than half require a special "card key" in order to use the station, making use of these stations less convenient than a typical gasoline station. Thus, only a small fraction of these stations could truly be considered to be a seed for a consumer market. ${ }^{7}$ Further, not only does a station need to be accessible to the average consumer for spillover to be possible, but it also must be located such that the average consumer will become aware of that station's existence. If the station is accessible but located in the back of an industrial facility, for instance, it is unlikely that the

\footnotetext{
${ }^{6}$ It is important to note that while acquisition of alternative-fuel vehicles was mandated, actual usage of alternative fuel was not mandated for federal and state fleets.

${ }^{7}$ Additional research would be required to identify precisely which CNG stations were conveniently accessible to the consumer. For instance, a CNG pump that required no special procedures for access and was located alongside a gasoline pump might be considered convenient for a mass-market consumer.
} 
average consumer will even learn of its existence, again limiting the effectiveness of this station as a seed for a consumer market. ${ }^{8}$

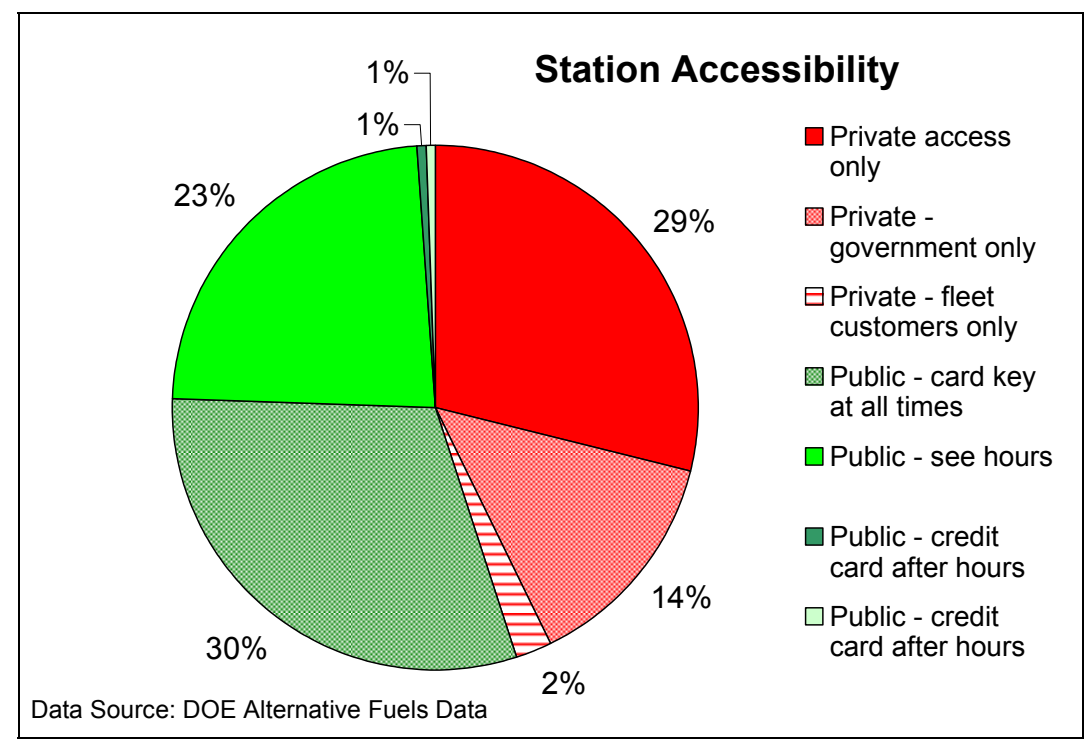

Figure 13: Accessibility of CNG Stations in CA (2002) [4]

On the other hand, a primarily consumer-driven approach that excludes any fleet component must still find a way to initially seed the positive feedback loops discussed in Section 5.3.2. A tipping-point will still exist that must be crossed by a sufficient quantity of refueling stations and vehicles, supported for a sufficient period of time (e.g., through government incentives), to establish a self-sustaining market. For advocates of a hydrogen transition, it seems to be accepted that some level of government incentives (for fueling stations and vehicles) will be required. Whether a fleet approach, a consumer-driven approach, or some combination thereof would be most cost effective remains to be seen. Further dynamic analysis, with explicit representation of both the fleet and consumer markets, as well as the spillover mechanisms between the two, could help to quantify the relative merits of these alternative approaches. In the end, a strategy that combines the advantages of a fleet approach (e.g., more easily mandated, potentially higher fuel usage, lower refueling risk, etc.) with the larger market potential of a consumer-driven approach may have a greater likelihood of success. The primary lesson, however, is that any approach (fleet, consumer-driven, or otherwise) must give due consideration to the mechanisms that would sufficiently seed the mass market. Failure to consider these mechanisms (e.g., ignoring the station accessibility/awareness issue) can be expected to result in premature market saturation, or even collapse upon removal of government incentives.

\footnotetext{
${ }^{8}$ Explicit representation of the mechanisms contributing to "awareness" of a refueling station, which can be expected to affect vehicle sales, is envisioned in later versions of HyDIVE.
} 


\subsection{Next Steps}

It is important to note that HyDIVE is in the early stages of development. Additional data gathering, model validation, model extensions, and policy analyses could enhance our understanding of previous alternative-fuel experiences as well as future hydrogen transition strategies. The following model extensions (the first three of which are discussed elsewhere [22] [12]) are under consideration, but could be tailored to objectives:

- the diffusion of technology awareness through experience and word-of-mouth;

- economies-of-scale and learning curve effects on manufacturing costs;

- technology performance improvements with time and research investment;

- improved spatial representation of consumer driving patterns (e.g., relax the assumption of radial symmetry of the trip distribution frequency and include actual driving pattern or density data);

- feedback of vehicle demand on resource availability and cost (e.g., natural gas and/or platinum);

- explicit representation of the economics of bi-fuel hydrogen/gasoline stations;

- explicit representation of potential spillover of a "fleet" market to a "consumer" market.

Additionally, upon sufficient model development and validation (facilitated by additional data collection - see Section 7.0), we anticipate addressing the following issues:

- assessment of alternate transition strategies;

- better quantification of the level and duration of subsidies required to seed a hydrogen vehicle and infrastructure market;

- identification of high leverage policies and incentives;

- evaluation of different spatial distributions of initial hydrogen refueling stations;

- improved understanding of the effect of various technology performance and cost targets. 


\subsection{References}

1. Energy Policy Act of 1992. 1992, P. Law 102-486.

2. National Academy of Engineering, B.o.E.a.E.S., The Hydrogen Economy: Opportunities, Costs, Barriers, and R\&D Needs. 2004, National Academies Press.

3. Melendez, M., NREL/TP-540-39423 -- Transitioning to a Hydrogen Future: Learning from the Alternative Fuels Experience. 2006.

4. US Department of Energy. Alternative Fuels Data Center: Finding a Fuel Station. [cited 2005 August]; Available from: http://www.eere.energy.gov/afdc/infrastructure/refueling.html.

5. Greene, D., et al., Hydrogen Transition Modeling and Analysis :HYTRANS v.1.0, in DOE Hydrogen, Fuel Cells \& Infrastructure Technologies Program Review. 2004.

6. Greene, D. ORNL/TM-2001/134: TAFV Alternative Fuels and Vehicles Choice Model Documentation. 2001 July [cited 2005 June]; Available from: http://www.osti.gov/bridge.

7. Conzelmann, G. Hydrogen Transition Modeling Using Complex Adaptive Systems Approach. [cited 2005 November 30]; Available from:

http://www.dis.anl.gov/CEEESA/hydrogen transition modeling.html.

8. Mintz, M. and G. Conzelmann, Phone conversation regarding the scope of RCF and ANL's Complex Adaptive System model. , C. Welch 2005.

9. Struben, J., Technology Transitions: identifying challenges for hydrogen fuel cell vehicles, in System Dynamics Conference. 2004: Oxford, England.

10. Struben, J., Deliverable 6.2 of Subcontract No. XCO-5-55516-01. Computer Model (Vensim DSS)- AFV_INFRA_SENSE_ICE_V27PUB. 2006, National Renewable Energy Laboratory.

11. Bullard, D., Subcontract No. XCO-5-55516-01. Transition to Alternative Fuel Vehicles: Spatial Coevolutionary Dynamics Between Vehicle Demand and Infrastructure Coverage. 2005, National Renewable Energy Laboratory.

12. Struben, J., Transition Challenges for Alternative Fuels in Transportation: Coevolutionary Dynamics of Vehicle Demand and Fueling Infrastructure. . working paper, 2006.

13. Sterman, J., Business Dynamics, Systems Thinking and Modeling for a Complex World. 2000: Irwin McGraw-Hill. 4-5, 12-13.

14. Struben, J. and J. Sterman, Transition challenges for alternative fuel vehicle and transportation systems. working paper, 2006.

15. Nicholas, M., Station Siting for the California Hydrogen Highway Network, in Hydrogen Case Studies Workshop. 2005: University of California, Davis.

16. Struben, J., Deliverable 6.4 of Subcontract No. XCO-5-55516-01. "The hydrogen transition challenge: co-evolutionary dynamics between vehicle demand and fueling station coverage". 2005, National Renewable Energy Laboratory.

17. US Census Bureau, Census 2000. 2000.

18. US Census Bureau, 2002 Zip Code Business Patterns. 2002.

19. Energy Information Administration. Table 4., Estimated Number of Alternative Fueled Vehicles in Use, by State and Fuel Type, 2002. [cited 2005 September]; Available from: http://www.eia.doe.gov/cneaf/alternate/page/datatables/afvtable4 03.xls.

20. D Brownstone and K. Small, Valuing Time and Reliability: Assessing the Evidence from Road Pricing Demonstrations. Transportation Research. Part A: Policy and Practice, 2005. 39(4): p. 279-293.

21. Davis, S., Transportation Energy Data Book. 21 ed. 2001, Oak Ridge: Oak Ridge National Laboratory.

22. Struben, J., Sustained alternative fuel vehicle adoption: learning and technology spillover tradeoffs. under preparation, 2006.

23. Struben, J., Deliverable 6.1 of Subcontract No. XCO-5-55516-01. "Memo - data needs for modeling project: Transitions to alternative fuels in transportation". 2006, National Renewable Energy Laboratory. 


\subsection{Appendices}

Appendix 1: Data Needs for Model Development and Validation [23]

\begin{tabular}{|c|c|c|c|}
\hline & Critical & Would be valuable & Comment \\
\hline \multicolumn{4}{|c|}{ General Data } \\
\hline $\begin{array}{l}\text { Population } \\
\text { [people] }\end{array}$ & $\begin{array}{l}\text { By LAT/LON for } \\
\text { US \& States: (esp. CA, } \\
\text { CO, MI, UT) }\end{array}$ & & \\
\hline $\begin{array}{l}\text { Vehicle Fleet } \\
\text { [vehicles] }\end{array}$ & $\begin{array}{l}\text { By Existing Fuel } \\
\text { Platformi for } \\
\text { US \& States: (esp. CA, } \\
\text { CO, MI, UT) } \\
\text { (professional / private) }\end{array}$ & $\begin{array}{l}\text { Time }(1970-2005 \text {, or } \\
\text { whatever available)By } \\
\text { LAT/LON }\end{array}$ & \\
\hline $\begin{array}{l}\text { Vehicle Sales } \\
\text { [vehicles/year] }\end{array}$ & $\begin{array}{l}\text { By Fuel Technology for } \\
\text { US \& States: (esp. CA, } \\
\text { CO, MI, UT) Over Time } \\
\text { (professional / private) }\end{array}$ & $\begin{array}{l}\text { Time (1970-2005, or } \\
\text { whatever available) }\end{array}$ & \\
\hline $\begin{array}{l}\text { Vehicle Miles } \\
\text { [miles/person/year] }\end{array}$ & $\begin{array}{l}\text { average annual per } \\
\text { person/ total } \\
\text { US \& States: (esp. CA, } \\
\text { CO, MI, UT) } \\
\text { (professional / private) }\end{array}$ & $\begin{array}{l}\text { By location, LAT/LON, } \\
\text { User Type }\end{array}$ & \\
\hline $\begin{array}{l}\text { Driving - Trip } \\
\text { Distance Frequency } \\
\text { [trips/year] }\end{array}$ & $\begin{array}{l}\text { Typical frequency } \\
\text { distribution of } \\
\text { households } \\
\text { (professional / private) } \\
\end{array}$ & $\begin{array}{l}\text { By Location (LAT/Lon), } \\
\text { user Type, including } \\
\text { direction }\end{array}$ & $\begin{array}{l}\text { Other indicators of } \\
\text { interest: interurban } \\
\text { traffic vs. local traffic } \\
\text { etc... }\end{array}$ \\
\hline $\begin{array}{l}\text { Median Driving } \\
\text { Distance [miles/trip] }\end{array}$ & $\begin{array}{l}\text { Typical median trip } \\
\text { distance for an } \\
\text { individuals } \\
\text { (professional / private) }\end{array}$ & $\begin{array}{l}\text { By Location (LAT/Lon), } \\
\text { user Type, including } \\
\text { direction } \\
\text { Mean trip distance }\end{array}$ & $\begin{array}{l}\text { A good first } \\
\text { approximation could be } \\
\text { home-work traffic by } \\
\text { zip code }\end{array}$ \\
\hline $\begin{array}{l}\text { Fuel Stations } \\
\text { [stations] }\end{array}$ & $\begin{array}{l}\text { By Existing Fuel } \\
\text { Platform } \\
\text { By LAT/LON for } \\
\text { States: CA, CO, MI, UT } \\
\text { (professional / private) }\end{array}$ & $\begin{array}{l}\text { Time }(1970-2005, \text { or } \\
\text { whatever available) }\end{array}$ & \\
\hline
\end{tabular}




\begin{tabular}{|c|c|c|c|}
\hline $\begin{array}{l}\text { Gasoline } \\
\text { Consumption } \\
\text { [gallons/year] }\end{array}$ & $\begin{array}{l}\text { average annual per } \\
\text { person/ total } \\
\text { US \& States: (esp. CA, } \\
\text { CO, MI, UT) } \\
\text { (professional / private) }\end{array}$ & $\begin{array}{l}\text { By location, LAT/LON, } \\
\text { User Type }\end{array}$ & \\
\hline \multicolumn{4}{|c|}{ Fuel Stations - Economic } \\
\hline $\begin{array}{l}\text { Gasoline Station } \\
\text { Capacity } \\
\text { [pumps/station] }\end{array}$ & $\begin{array}{l}\text { Average pumps per } \\
\text { station by type of region } \\
\text { (urban/rural) for } \\
\text { US }\end{array}$ & $\begin{array}{l}\text { States: (esp. CA, CO, } \\
\text { MI, UT) }\end{array}$ & \\
\hline $\begin{array}{l}\text { Fixed Cost per } \\
\text { Station } \\
\text { [\$/gallon equivalent } \\
\text { (capacity)/year] }\end{array}$ & $\begin{array}{l}\text { Average, by platform, } \\
\text { by type of region } \\
\text { (urban/rural) for } \\
\text { US }\end{array}$ & $\begin{array}{l}\text { States: (esp. CA, CO, } \\
\text { MI, UT) }\end{array}$ & $\begin{array}{l}\text { Should be broken down } \\
\text { into most relevant } \\
\text { factors (e.g. capital, cost } \\
\text { of capital, O\&M, rent } \\
\text { etc..). Currently use data } \\
\text { from H2A for } \\
\text { alternative fuels, seeking } \\
\text { data for gasoline, CNG, }\end{array}$ \\
\hline $\begin{array}{l}\text { Variable Cost per } \\
\text { Station } \\
\text { [\$/gallon equivalent } \\
\text { (consumed)] }\end{array}$ & $\begin{array}{l}\text { Average, by platform, } \\
\text { by type of region } \\
\text { (urban/rural) for US \& }\end{array}$ & $\begin{array}{l}\text { States: (esp. CA, CO, } \\
\text { MI, UT) }\end{array}$ & $\begin{array}{l}\text { Should be broken down } \\
\text { into most relevant } \\
\text { factors (feedstock, } \\
\text { energy etc..)Currently } \\
\text { use data from H2A for } \\
\text { alternative fuels, seeking } \\
\text { data for gasoline, CNG, }\end{array}$ \\
\hline $\begin{array}{l}\text { Ancillary sales per } \\
\text { station [\$/visit] }\end{array}$ & $\begin{array}{l}\text { \$ value per customer } \\
\text { visit }\end{array}$ & & \\
\hline $\begin{array}{l}\text { Average refueling } \\
\text { rate } \\
\text { [minutes/gallon } \\
\text { equivalent/pump] }\end{array}$ & By platform (type) & & $\begin{array}{l}\text { Currently use data from } \\
\text { H2A for alternative } \\
\text { fuels, seeking data for } \\
\text { gasoline, } \mathrm{CNG} \text {, }\end{array}$ \\
\hline $\begin{array}{l}\text { Land Rent Cost } \\
\text { [\$/acre/year] or } \\
\text { [\$/gallons } \\
\text { (capacity)/year] }\end{array}$ & $\begin{array}{l}\text { Total per region } \\
\text { (average per station } \\
\text { capacity, by region) } \\
\text { - urban/rural }\end{array}$ & $\begin{array}{l}\text { for } \\
\text { US \& States: (esp. CA, } \\
\text { CO, MI, UT) } \\
\text { For particular } \\
\text { metropolitan areas } \\
\end{array}$ & \\
\hline $\begin{array}{l}\text { Station permitting } \\
\text { time [years/permit] }\end{array}$ & $\begin{array}{l}\text { Average by type of } \\
\text { region (urban/rural) for } \\
\text { US }\end{array}$ & & \\
\hline $\begin{array}{l}\text { Station expansion } \\
\text { time [years/permit] }\end{array}$ & $\begin{array}{l}\text { Average by type of } \\
\text { region (urban/rural) for } \\
\text { US }\end{array}$ & & \\
\hline $\begin{array}{l}\text { Station construction } \\
\text { time [years/permit] }\end{array}$ & $\begin{array}{l}\text { Average by type of } \\
\text { region (urban/rural) for } \\
\text { US }\end{array}$ & & \\
\hline
\end{tabular}




\begin{tabular}{|c|c|c|c|}
\hline $\begin{array}{l}\text { Gasoline Sales } \\
\text { [gallons/year/station] }\end{array}$ & $\begin{array}{l}\text { Average annual per } \\
\text { station by region } \\
\text { (urban/rural) for } \\
\text { US \& States: (esp. CA, } \\
\text { CO, MI, UT) }\end{array}$ & $\begin{array}{l}\text { By zone LAT/LON, } \\
\text { User Type }\end{array}$ & \\
\hline \multicolumn{4}{|c|}{ Drivers - Economic } \\
\hline $\begin{array}{l}\text { Fuel efficiency } \\
\text { [miles/gallon } \\
\text { equivalent/vehicle] }\end{array}$ & $\begin{array}{l}\text { By model year/average } \\
\text { for fleet, by vehicle } \\
\text { type, per platform }\end{array}$ & & $\begin{array}{l}\text { Currently use Heywood } \\
\text { study and Greet } \\
\text { Databases }\end{array}$ \\
\hline $\begin{array}{l}\text { Tank size [gallon } \\
\text { equivalent/vehicle } \\
\text { type] }\end{array}$ & $\begin{array}{l}\text { By model year/average } \\
\text { for fleet, by vehicle } \\
\text { type, per platform }\end{array}$ & & \\
\hline \multicolumn{4}{|c|}{ Fuel Stations - Behavioral } \\
\hline $\begin{array}{l}\text { Entry/Exit, location } \\
\text { heuristics in general }\end{array}$ & & $\begin{array}{l}\text { Interviews with pump } \\
\text { owners (individual / oil } \\
\text { companies) }\end{array}$ & \\
\hline \multicolumn{4}{|c|}{ Drivers - Behavioral } \\
\hline $\begin{array}{l}\text { Value of time } \\
\text { [\$/hour] }\end{array}$ & $\begin{array}{l}\text { Longer distance, short } \\
\text { distance, waiting for } \\
\text { service, by user group }\end{array}$ & & $\begin{array}{l}\text { Currently base ourselves } \\
\text { on studies in } \\
\text { transportation research } \\
\text { (Ben-Akiva, Small, } \\
\text { McFadden, Train,...) }\end{array}$ \\
\hline $\begin{array}{l}\text { Cost of out of fuel } \\
\text { [\$/out of fuel] }\end{array}$ & $\begin{array}{l}\text { Time / Opportunity } \\
\text { costs, and dollars spent } \\
\text { per out of fuel }\end{array}$ & & \\
\hline $\begin{array}{l}\text { Sensitivity of driving } \\
\text { behavior to } \\
\text { alternative modes of } \\
\text { transportation }\end{array}$ & tbd & & $\begin{array}{l}\text { Currently base ourselves } \\
\text { on studies in } \\
\text { transportation research } \\
\text { (Ben-Akiva, Small, } \\
\text { McFadden, Train,...) }\end{array}$ \\
\hline $\begin{array}{l}\text { Responsiveness to } \\
\text { risk/ effort }\end{array}$ & & $\begin{array}{l}\text { Literature review on this } \\
\text { topic }\end{array}$ & $\begin{array}{l}\text { Currently base ourselves } \\
\text { on studies in } \\
\text { transportation research } \\
\text { (Ben-Akiva, Small, } \\
\text { McFadden, Train,...) }\end{array}$ \\
\hline \multicolumn{4}{|c|}{ Infrastructure - General } \\
\hline $\begin{array}{l}\text { Directed Road } \\
\text { Capacity } \\
\text { [vehicles/hour/zone] }\end{array}$ & & $\begin{array}{l}\text { California by LAT/LON } \\
\text { zones (e.g. 10x10 } \\
\text { miles), through-flow } \\
\text { capacity }\end{array}$ & \\
\hline $\begin{array}{l}\text { Directed Traffic Flow } \\
\text { [vehicles/hour/zone] }\end{array}$ & & $\begin{array}{l}\text { California by LAT/LON } \\
\text { zones (e.g. 10x10 } \\
\text { miles), in/out through } \\
\text { edges of zone (N/S/WE) }\end{array}$ & \\
\hline
\end{tabular}

\footnotetext{
${ }^{\mathrm{i}}$ Existing Fuel Platform (Vehicle/Fuel): ICE/Gasoline, ICE/Natural Gas, ICE/E85 (where relevant)
} 


\section{REPORT DOCUMENTATION PAGE}

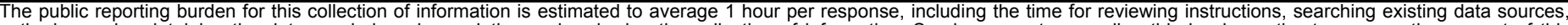

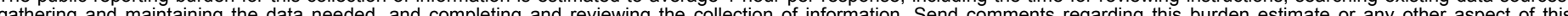

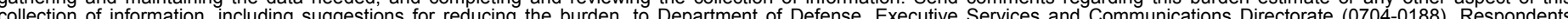

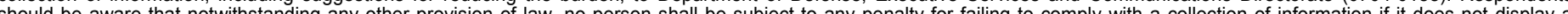

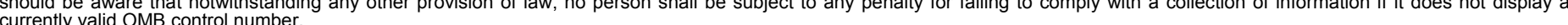

PLEASE DO NOT RETURN YOUR FORM TO THE ABOVE ORGANIZATION.
1. REPORT DATE (DD-MM-YYYY)
February 2006
2. REPORT TYPE
Technical Report
4. TITLE AND SUBTITLE
Lessons Learned from Alternative Transportation Fuels: Modeling
Transition Dynamics

3. DATES COVERED (From - To)

5a. CONTRACT NUMBER

DE-AC36-99-G010337

5b. GRANT NUMBER

5c. PROGRAM ELEMENT NUMBER

6. AUTHOR(S)

C. Welch

5d. PROJECT NUMBER

NREL/TP-540-39446

5e. TASK NUMBER

HS06.1002

5f. WORK UNIT NUMBER

7. PERFORMING ORGANIZATION NAME(S) AND ADDRESS(ES)

National Renewable Energy Laboratory

1617 Cole Blvd.

8. PERFORMING ORGANIZATION REPORT NUMBER

Golden, CO 80401-3393

NREL/TP-540-39446

9. SPONSORING/MONITORING AGENCY NAME(S) AND ADDRESS(ES)

10. SPONSOR/MONITOR'S ACRONYM(S) NREL

11. SPONSORING/MONITORING AGENCY REPORT NUMBER

12. DISTRIBUTION AVAILABILITY STATEMENT

National Technical Information Service

U.S. Department of Commerce

5285 Port Royal Road

Springfield, VA 22161

13. SUPPLEMENTARY NOTES

14. ABSTRACT (Maximum 200 Words)

Report focuses on understanding how analytical system modeling and data from AFV experiences could improve our understanding of the dynamic forces governing the transition to a hydrogen future.

15. SUBJECT TERMS

Hydrogen transition; alternative fuel vehicles; analytical system modeling; HyDIVE; hydrogen infrastructure; refueling stations

\begin{tabular}{|c|c|c|}
\hline 16. SECURIT & CLASSIFICATI & N OF: \\
\hline $\begin{array}{l}\text { a. REPORT } \\
\text { Unclassified }\end{array}$ & $\begin{array}{l}\text { b. ABSTRACT } \\
\text { Unclassified }\end{array}$ & $\begin{array}{l}\text { c. THIS PAGE } \\
\text { Unclassified }\end{array}$ \\
\hline
\end{tabular}

\begin{tabular}{|c|c|}
\hline $\begin{array}{l}\text { 7. LIMITATION } \\
\text { OF ABSTRACT }\end{array}$ & $\begin{array}{l}\text { 18. NUMBER } \\
\text { OF PAGES }\end{array}$ \\
\hline UL & \\
\hline
\end{tabular}

19a. NAME OF RESPONSIBLE PERSON

19b. TELEPHONE NUMBER (Include area code) 